$1-1-1982$

\title{
Monongalia area survey, 1981 : citizens' views on industrial development and quality of life
}

Nancy Stout-Wiegand

Roger W. Trent

Dennis K. Smith

Follow this and additional works at: https://researchrepository.wvu.edu/ wv_agricultural_and_forestry_experiment_station_bulletins

\section{Digital Commons Citation}

Stout-Wiegand, Nancy; Trent, Roger W.; and Smith, Dennis K., "Monongalia area survey, 1981 : citizens' views on industrial development and quality of life" (1982). West Virginia Agricultural and Forestry Experiment Station Bulletins. 676.

https://researchrepository.wvu.edu/wv_agricultural_and_forestry_experiment_station_bulletins/573 

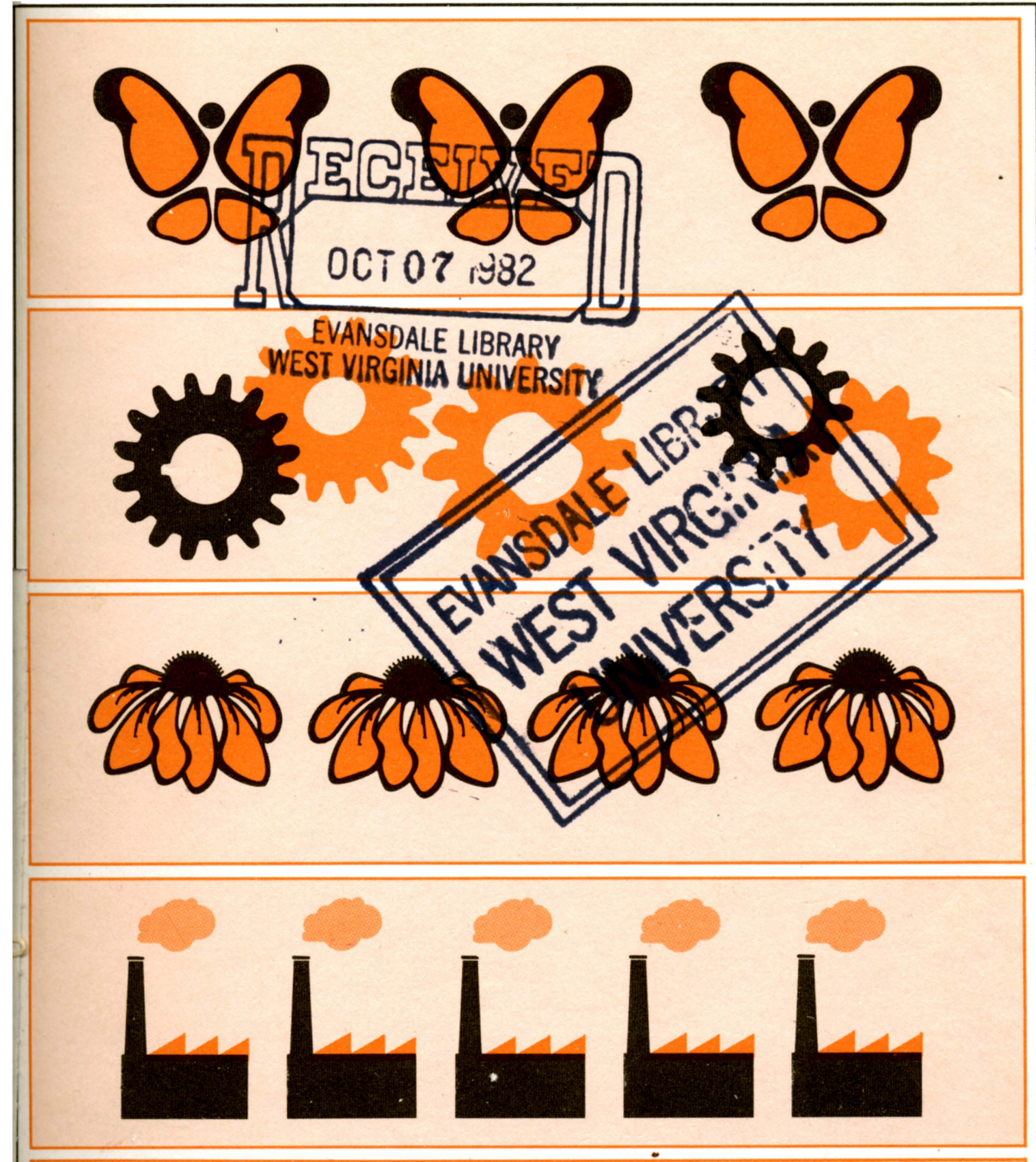

\section{Monongalia Area Survey, 1981:} Citizens' Views on Industrial Development and Quality of Life

West Virginia University

Agricultural and Forestry Experiment Station

Bulletin 676

August 1982 


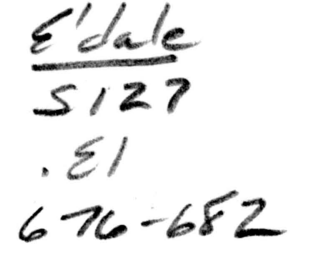

\section{Authors}

Nancy Stout-Wiegand is Research Associate in the Division of Resource Management, College of Agriculture and Forestry, West Virginia University; Roger B. Trent is Associate Professor and Associate Chairman of the Department of Sociology and Anthropology, College of Arts and Sciences, West Virginia University; and Dennis K. Smith is Associate Professor of Agricultural Economics, Division of Resource Management, College of Agriculture and Forestry, West Virginia University.

\section{Acknowledgments}

The authors acknowledge the financial support for the project of the West Virginia University (WVU) Energy Research Center, and the WVU Division of Resource Management. This publication was partially funded by Title V, Rural Development Act of 1972. We also appreciate the encouragement and support of M. Dayne Aldridge, Director for Energy Research. The authors appreciate the dedicated efforts of the interviewers: Marcia Baniak, Joy Boguszewski, Patricia Evich, Robert Frame, Cheryl Lockhart, Terry Moore, Lisa Nogosky, Terry Ridenour, Greg Sayre, Melanie Sokolosky, and Thomas Yocum. The authors also appreciate the helpful comments of the reviewers of the manuscript: Robert Jack, Layle Lawrence, and Delmar Yoder.

The authors alone are responsible for the analysis and interpretation of the data presented in this report.

West Virginia University

Agricultural and Forestry Experiment Station College of Agriculture and Forestry

Dale W. Zinn, Director

Morgantown 


\section{CONTENTS}

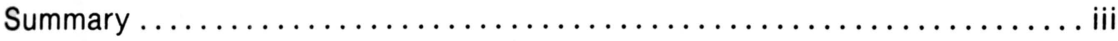

Purpose of the Monongalia Area Survey $\ldots \ldots \ldots \ldots \ldots \ldots \ldots \ldots \ldots$

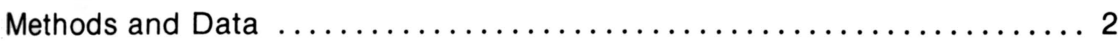

A Portrait of Survey Respondents $\ldots \ldots \ldots \ldots \ldots \ldots \ldots \ldots \ldots \ldots \ldots 4$

Assessments of the Quality of Life in the Monongalia Area $\ldots . \ldots \ldots \ldots 11$

Assessments of Local Services and Facilities .................. 17

Purchasing Patterns of Townspeople and Students $\ldots \ldots \ldots \ldots \ldots \ldots 20$

Attitudes Toward Energy-Related Development ................ 25

Who Favors and Who Opposes the Proposed Industries? .......... 31

How are Students Different from Other Area Residents? ........... 40

Discussion...................................... 45

\section{TABLES}

Table 1. The Distribution of Demographic Characteristics of the Sample ................................ 5

Table 2. Attitudes Toward the Local Area $\ldots \ldots \ldots \ldots \ldots \ldots \ldots \ldots . \ldots 12$

Table 3. Attitudes Toward Energy-Related Industries.............. 25

Table 4. Comparison of Students and Townspeople According to Age, Dwelling Unit Status (own/rent) and Amount of Monthly Rent................................ 41

Table 5. Comparison of Students and Townspeople in Recognition Factors and Favorability Toward Four Proposed Industries

Table 6. Comparison of Students and Townspeople According to Attitudes Toward Local Development Projects.............. 43

Table 7. Comparison of Students and Townspeople According to Energy/Environment and Economic Growth/Environment Trade-offs 


\section{FIGURES}

Figure 1. Monongalia County Map Showing the Survey Area $\ldots \ldots \ldots 3$

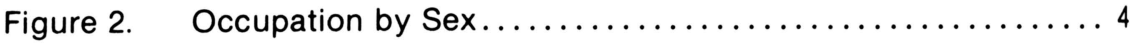

Figure 3. Energy-Related Occupation by Sex ............... 10

Figure 4. Household Income by Sex...................... 11

Figure 5. Perceived Problem of Air Pollution by Sex ........... 16

Figure 6. Perceived Problem of Traffic Congestion by Sex......... 17

Figure 7. Respondent Satisfaction with Local Services ........... 18

Figure 8. How Much Heard About Industries by Sex ............ 29

Figure 9. Favoring Versus Opposing Industries by Sex .......... 29

Figure 10. How Respondent Would Vote Toward Industries by Sex ... 30

Figure 11. Approval of Hypothetical Industries with

Varying Characteristics......................... 32

Figure 12. Perceived Benefit of New Industries by Favoring

Versus Opposing New Industries .................. 33

Figure 13. Perceived Benefit of New Industries by Education ....... 34

Figure 14. Perceived Benefit of New Industries by Occupation Class .. 34

Figure 15. Perceived Benefit of New Industries by Energy-

Related Occupation ........................... 35

Figure 16. Perceived Benefit of New Industries by How Proud of Local Area ................................ 35

Figure 17. Perceived Benefit of New Industries by Good Place to Raise Children .............................. 36

Figure 18. Perceived Benefit of New Industries by Desired Change in Local Population ...................... 36

Figure 19. Perceived Benefit of New Industries by Environment Versus Energy ............................. 37

Figure 20. Perceived Benefit of New Industries by Environment Versus Economic Growth ...................... 37

Figure 21. Perceived Benefit of New Industries by Perceived Problem of Air Pollution .......................... 38

Figure 22. Perceived Benefit of New Industries by Perceived Problem of Water Pollution ....................... 38

Figure 23. Comparison of Students and Townspeople According to Monthly Rent .............................. 41 


\section{Summary}

The Monongalia Area Survey (MAS) is a poll of 703 townspeople and students who live in an area likely to be the focus of coal-based energy developments. The MAS is a comprehensive citizen survey aimed at providing detailed knowledge of certain attitudes, and economic and social conditions to help both leaders and ordinary citizens make informed decisions about the future of the Monongalia area.

The MAS showed respondents (townspeople are referred to as "respondents," while students are simply called "students" in this report) to be predominately middle-aged, to have a high prevalence of home-ownership, and to have lived in the area for a relatively long time. Both blue and white collar occupations are well represented, and a large proportion of employed respondents work in some part of the "energy industry." Many of the respondents are not empicyed by virtue of their advanced age or their roles as homemakers.

Quality of life in the Monongalia area was generally rated high, with respondents often mentioning that they appreciate the rural, peaceful atmosphere, the friendly people, and the availability of West Virginia University. On the other hand, respondents were not happy with roads, employment opportunities, and parking and traffic congestion. There is some indication that housing is considered a problem. Air and water pollution were cited as problems by a significant percentage of the respondents.

Some local services were rated highly by respondents (especially ambulance, health and fire protection services); however, indoor recreation facilities, housing availability and quality, and road maintenance did not receive high marks. All local services are affected by industrial development, but those rated as inadequate are in danger of becoming major problems if there is much local growth.

Townspeople report making most expenditures for autos, auto maintenance and household durables in Monongalia County, but a good deal of the money spent on clothing leaves the county. Much gasoline purchased by townspeople is bought outside the county. Expenditures by students on food, clothing, transportation, and rent adds up to a major local economic impact in this area.

When asked to react to four industrial developments proposed for the Monongalia area (SRC-II Coal Liquefaction Plant, Roundbottom Coke Plant, Sharon Coke Plant, and Industrial Park), most respondents were aware of the SRC-II Plant and the Roundbottom Plant, but awareness of the Sharon Coke Plant and the Industrial Park was fairly low. Of those who were aware of each proposed development, a majority favored the SRC-II Plant and the Industrial Park, a plurality favored the Sharon Plant, and opinion was split on the Roundbottom Plant. Respondents saw both benefits to industrial development (e.g., more jobs, more business) and liabilities (e.g., crowdedness, pollution), and many people believed planning should precede industrial development.

MAS respondents proved to have a fairly strong desire to protect the environment, often at the expense of energy development and economic growth, but this concern does not generally translate into an anti-growth stance. Area residents express strong desires for both development and 
protection of the area's living environment rather than one at the expense of the other. Residents favor locally employing industries primarily, with industry cleanliness seen as a secondary desirable characteristic of industries. Coalbased industries had less local support than clean and locally employing industries.

The belief that local industrial development would be beneficial for the area was strongest among less-educated respondents, blue collar and service workers, those working in energy-related jobs, and people who are proud of the area. Respondents concerned with environmental problems tend to be less enthusiastic about the benefits of local development. In general, development attitudes appear to reflect economic self-interest; nevertheless, other factors also influence these attitudes, particularly concern with the quality of life in the Monongalia area.

Students in the study area appear to be nearly as approving of proposed industries as townspeople. Indeed, students appear to be even more firmly committed to growth coupled with protection of the environment. The differences between students and townspeople in age, style of living and attachment to the local area, do not result in very different attitudes toward local development. 


\section{Monongalia Area Survey, 1981: Citizens' Views on Industrial Development and Quality of Life}

Nancy Stout-Wiegand, Roger B. Trent, and Dennis K. Smith

\section{PURPOSE OF THE MONONGALIA AREA SURVEY}

As the United States turns back to coal for energy, Appalachia finds itself, once again, preparing for the opportunities and strains that will come with development. Monongalia County, West Virginia, a center of the Appalachian bituminous coal industry, will no doubt experience changes in the next decade as vast as any it experienced in the last half century. The near-certainty of new industry and a changed way of living prompted us to design this social survey of the Monongalia County area. The Monongalia Area Survey (MAS) is a citizen survey aimed at learning how people feel about industries proposed for the area, how they assess their quality of life, and how they perceive local public services and facilities.

This information was sought for two reasons. First, citizens' perceptions of life in this area have not been assessed in recent years and residents' opinions toward industrial development in this area have never been determined. Local government and decision-making bodies have had to rely on their own judgment about the needs and concerns of the community. Although residents with strong opinions, especially concerning proposed industries, often let their feelings be known in public meetings and the media, opinions of the entire community have never been determined. Therefore, this survey should be extremely useful to local governing and planning bodies by providing recent information about residents' attitudes toward the local area, public services, and industrial development.

The second purpose of this survey is to establish a baseline profile of both the demographic composition of the area and of residents' perceptions and attitudes. Data collected in the future can be compared with this baseline in order to measure changes in the quality of life that inevitably accompany growth and development.

So little research has been done on the impacts of industrialization on rural Appalachian communities that we cannot predict what will happen in such an area when it becomes industrially developed-how the composition of the population changes, how residents feel about the industries and their effects, how expenditure patterns change, what public services and facilities become inadequate, and how the overall quality of life is affected. As energy-related 
industries develop throughout the country, and especially in the eastern coal fields of Appalachia, government and private agencies will need answers to these questions if they are to control growth and protect the things we value. By establishing a baseline profile of the area at the same time as the 1980 census, it will be possible to measure changes and consequently to predict the kinds of changes we can expect when an Appalachian community begins to experience industrialization. It is our intention to repeat this survey in the Spring of 1982, and thereafter on an annual basis if possible, in order to document changes and to develop methods of forecasting the social and economic impacts of industrial development on Appalachian communities in general and in the Monongalia area in particular. An additional benefit of a survey repeated at intervals is the planning information that would be available to leaders in government, industry, and citizen organizations. To respond properly to changing conditions, accurate, timely information is a necessity. Only carefully conducted sample surveys can provide this information on the needs and desires of citizens in the Monongalia area.

\section{METHODS AND DATA}

The Monongalia area-the study area of this research-consists of the Morgantown area (including Granville, Westover, Star City, Cassville, and Osage, W. Va.), the borough of Point Marion, $\mathrm{Pa}$. and the a rea of Mount Morris, $\mathrm{Pa}$. which is served by the Morgantown telephone exchange (Figure 1). Given existing residential and transportation patterns, this area was considered to be the primary impact area of the proposed new industries.

Respondents were contacted by telephone using the random digit dialing method of sampling. With this method, residential telephone numbers were drawn at random from the Morgantown telephone directory (which includes listings for the entire Monongalia area) and the last two digits of each number were replaced with random digits from a table of random numbers. This method of telephone sampling tends to avoid non-residential listings while including unlisted residential numbers, and most importantly, it assures our respondents that their answers will be anonymous.

The study area includes West Virginia University, and many students live in private housing in and around Morgantown. Students who live in private housing were included in the survey. Students residing in WVU-owned housing were excluded from the sample, partly because it is difficult to sample them on the same basis as residents in private housing. Since most of the excluded students are freshmen, and most are fairly new to this area, we are in essence excluding a small number of newcomers. The freshmen students who continue their studies at WVU will be eligible for inclusion in future surveys. By then, they will have been residents of this area long enough to have developed informed opinions. Although students are quite different from more permanent members of the community, their opinions are important and worthy of consideration, so a special student interview schedule was 
Figure 1.

Monongalia County map showing

the survey area

\section{Pennsylvania}

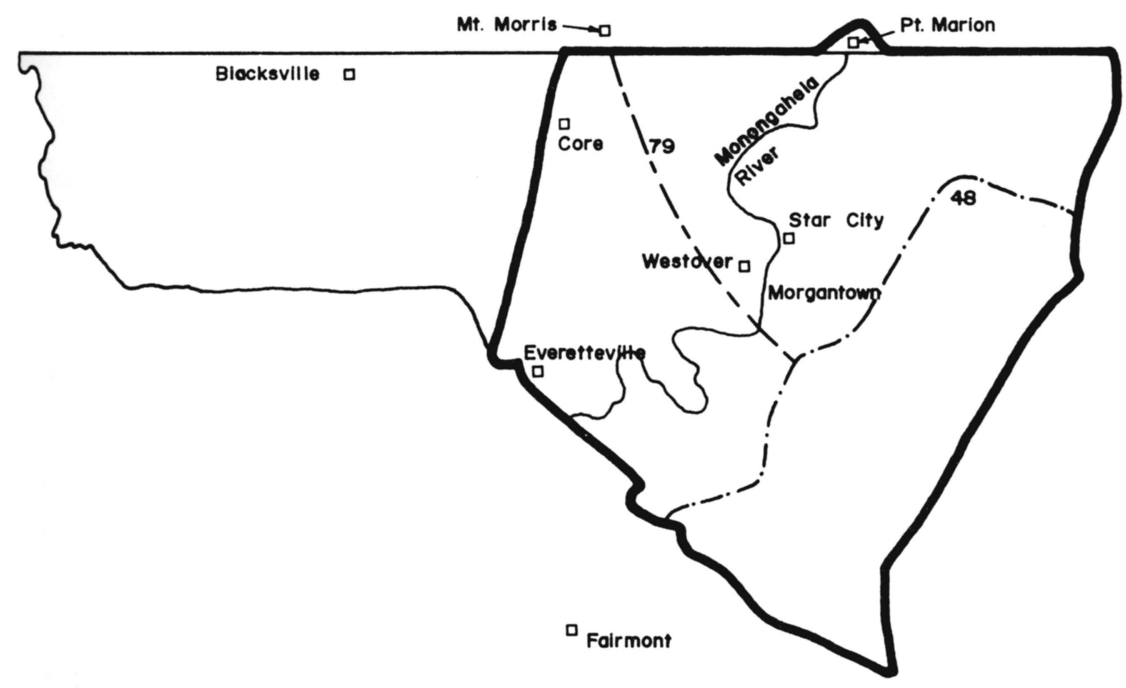

developed to help us assess students as a special population with special interests. Data from the student interviews are presented separately from those of townspeople in this report.

During a two-week period in March and April, 1981, a team of specially trained interviewers contacted respondents between 5:30 and 9:30 p.m. on week days and 11:00 a.m. to 9:00 p.m. on Saturdays and Sundays. The authors felt that by avoiding the normal working hours of the week they would reduce the bias toward females and the unemployed that is inherent in telephone surveys.

Of the 1,167 respondents contacted, 713 interviews were completed-a response rate of 61 percent. Eight of the interviews were not usable and 220 were from students, leaving 485 interviews of townspeople. Most of this report is based on the 485 townspeople sample. Students' responses are analyzed separately in the final section. 
Two forms of data presentation appear in this report: percentage distributions and bar graphs. Neither of these devices should be difficult for the reader to understand; however, some of the bar graphs are broken down according to a second factor, an example of which would be Figure 2, respondent's occupation broken down by sex. This double bar graph is selfexplanatory, but the statistics under the graph may be confusing. These measures are included as an aid for the reader familiar with statistics, but one of the statistics can be easily understood by all. "P" is the probability that differences between the groups represented by the bars are due to chance sampling error rather than a true difference. In the case of Figure 2, the occupational difference between male and female respondents in the sample is so large that there is only one chance in 10,000 that the difference can be attributed to sampling error rather than true differences between males anc females in the population studied. This provides a method for deciding how bic a difference has to be before it can be assumed that it is a true difference. By convention, differences are accepted if the $P$ value is smaller than .05 ; in othe words, unless we can be 95 percent confident in our findings we will no assume that there is any statistically significant finding at all. $P$ values large than .05 are called "not statistically significant," and are assumed to represen nothing more than a chance fluctuation resulting from the fact that we are using a sample rather than the entire population.

\section{PORTRAIT OF SURVEY RESPONDENTS}

The survey data were tabulated in terms of five main categories: (1) demographic characteristics of respondents and households, (2) attitudes toward the local area, (3) satisfaction with local services, (4) purchasins patterns of residents and students, and (5) attitudes toward the proposed nev energy-related industries.

\section{Figure 2. Occupation by sex}

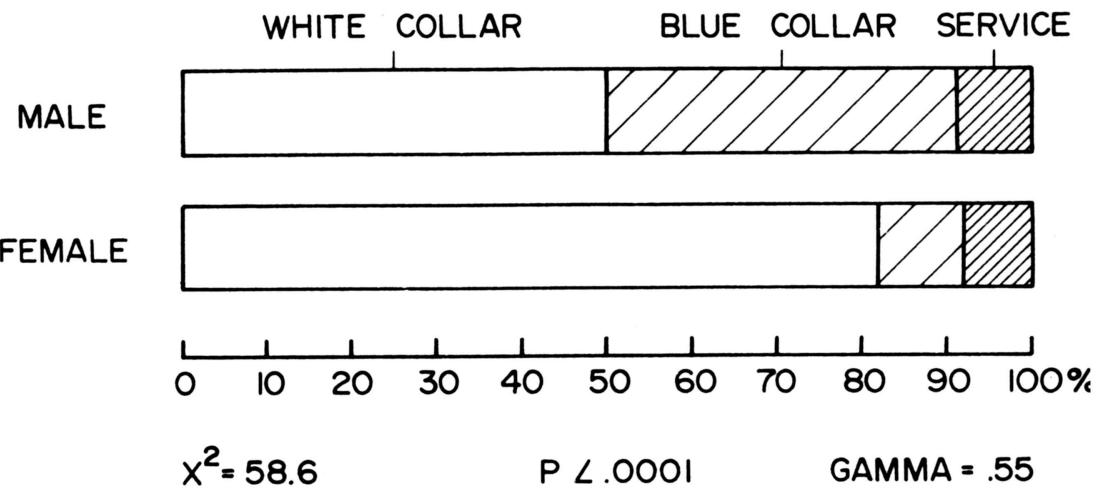


This section describes the demographic characteristics of the non-student respondents-the townspeople. Distributions of these characteristics are presented in Table 1.

Table 1.

Distribution of Demographic Characteristics of the Sample:

Monongalia Area Survey, 1981.

\begin{tabular}{|c|c|c|c|}
\hline QUESTION & & $\mathbf{N}$ & $\%$ \\
\hline$\overline{\operatorname{Sex}}$ & $\begin{array}{l}\text { Male } \\
\text { Female }\end{array}$ & $\begin{array}{l}188 \\
296\end{array}$ & $\begin{array}{l}39 \\
61\end{array}$ \\
\hline Age & $\begin{array}{l}18-25 \\
26-30 \\
31-35 \\
36-40 \\
41-45 \\
46-50 \\
51-55 \\
56-60 \\
61-65 \\
66-70 \\
>70\end{array}$ & $\begin{array}{r}67 \\
81 \\
52 \\
43 \\
31 \\
0 \\
34 \\
41 \\
39 \\
32 \\
26\end{array}$ & $\begin{array}{r}15 \\
18 \\
12 \\
10 \\
7 \\
0 \\
7 \\
9 \\
9 \\
7 \\
6\end{array}$ \\
\hline Dwelling type & $\begin{array}{l}\text { House } \\
\text { Apartment } \\
\text { Mobile Home } \\
\text { Duplex/townhouse }\end{array}$ & $\begin{array}{r}346 \\
55 \\
76 \\
8\end{array}$ & $\begin{array}{r}71 \\
11 \\
16 \\
2\end{array}$ \\
\hline Do you own or rent your residence & $\begin{array}{l}\text { Own } \\
\text { Rent } \\
\text { Other }\end{array}$ & $\begin{array}{r}374 \\
105 \\
6\end{array}$ & $\begin{array}{r}77 \\
22 \\
1\end{array}$ \\
\hline Monthly Rent & $\begin{array}{l}<100 \\
\$ 100-150 \\
\$ 151-200 \\
\$ 201-250 \\
\$ 251-300 \\
\$ 301-350 \\
\$ 351-400 \\
\$ 401-450 \\
>\$ 450 \\
\text { Don't know } \\
\text { Refuse }\end{array}$ & $\begin{array}{r}3 \\
22 \\
13 \\
18 \\
25 \\
16 \\
1 \\
2 \\
0 \\
2 \\
5\end{array}$ & $\begin{array}{r}3 \\
21 \\
12 \\
17 \\
23 \\
15 \\
1 \\
2 \\
0 \\
2 \\
5\end{array}$ \\
\hline Length of time lived in county & $\begin{array}{l}\text { Less than } 5 \text { years } \\
6-10 \text { years } \\
11-20 \text { years } \\
21-30 \text { years } \\
31-50 \text { years } \\
\text { More than } 50 \text { years }\end{array}$ & $\begin{array}{c}87 \\
56 \\
74 \\
75 \\
99 \\
72 \\
\text { (contir }\end{array}$ & $\begin{array}{l}19 \\
12 \\
16 \\
16 \\
21 \\
16 \\
\text { lued) }\end{array}$ \\
\hline
\end{tabular}


Table 1. (Continued)

\begin{tabular}{|c|c|c|c|}
\hline QUESTION & & $\mathbf{N}$ & $\%$ \\
\hline Length of time lived in state & $\begin{array}{l}\text { Less than } 5 \text { years } \\
6-10 \text { years } \\
11-20 \text { years } \\
21-30 \text { years } \\
31-50 \text { years } \\
\text { More than } 50 \text { years }\end{array}$ & $\begin{array}{r}46 \\
31 \\
57 \\
98 \\
116 \\
114\end{array}$ & $\begin{array}{r}10 \\
7 \\
12 \\
21 \\
25 \\
25\end{array}$ \\
\hline Marital Status & $\begin{array}{l}\text { Single } \\
\text { Separated/divorced } \\
\text { Widowed } \\
\text { Married }\end{array}$ & $\begin{array}{r}70 \\
44 \\
51 \\
319\end{array}$ & $\begin{array}{r}14 \\
9 \\
10 \\
66\end{array}$ \\
\hline Number of children in household & $\begin{array}{l}0 \\
1 \\
2 \\
3 \\
4 \\
5 \\
6 \\
7\end{array}$ & $\begin{array}{r}251 \\
105 \\
84 \\
29 \\
9 \\
2 \\
2 \\
1\end{array}$ & $\begin{array}{r}52 \\
22 \\
17 \\
6 \\
2 \\
<1 \\
<1 \\
<1\end{array}$ \\
\hline Total persons in household & $\begin{array}{l}1 \\
2 \\
3 \\
4 \\
5 \\
6 \\
7 \\
8 \\
9\end{array}$ & $\begin{array}{r}81 \\
164 \\
107 \\
82 \\
34 \\
9 \\
3 \\
2 \\
1\end{array}$ & $\begin{array}{r}17 \\
34 \\
22 \\
17 \\
7 \\
2 \\
1 \\
<1 \\
<1\end{array}$ \\
\hline $\begin{array}{l}\text { Respondent education } \\
\text { (grades completed) }\end{array}$ & $\begin{array}{l}<8 \text { grades } \\
8-11 \text { grades } \\
\text { H.S. diploma } \\
\text { Post-H.S. ed., not } \\
\text { college } \\
\text { Some college } \\
\text { Bachelor degree } \\
\text { College beyond } \\
\text { bachelors }\end{array}$ & $\begin{array}{r}22 \\
72 \\
148 \\
\\
22 \\
70 \\
61 \\
\\
57\end{array}$ & $\begin{array}{r}5 \\
15 \\
31 \\
\\
5 \\
14 \\
13 \\
12\end{array}$ \\
\hline & Ph.D., MD, DDS, etc. & 31 & 6 \\
\hline Respondent employed & $\begin{array}{l}\text { Full-time } \\
\text { Part-time } \\
\text { No }\end{array}$ & $\begin{array}{r}252 \\
41 \\
190\end{array}$ & $\begin{array}{r}52 \\
8 \\
39\end{array}$ \\
\hline Looking for a job (unemployed) & $\begin{array}{l}\text { Yes } \\
\text { No }\end{array}$ & $\begin{array}{r}29 \\
165\end{array}$ & $\begin{array}{l}15 \\
85\end{array}$ \\
\hline
\end{tabular}




\section{QUESTION \\ Why not looking for a job}

Respondent occupation

Energy-related occupation

Years at current job

Spouse age group

Spouse education level (grades completed)

$\begin{array}{lrr}\text { Retired } & 76 & 46 \\ \text { Disabled } & 10 & 6 \\ \text { Housewife } & 48 & 29 \\ \text { Young children } & 14 & 8 \\ \text { Student } & 4 & 2 \\ \text { Other } & 14 & 8 \\ \text { Professional/technical } & 99 & 34 \\ \text { Manager/administrator } & 33 & 11 \\ \text { Sales } & 20 & 7 \\ \text { Clerical } & 39 & 13 \\ \text { Craftsmen/foremen } & 37 & 13 \\ \text { Operative } & 28 & 10 \\ \text { Transportation } & & \\ \quad \text { operative } & 3 & 1 \\ \text { Laborer } & 5 & 2 \\ \text { Farmer/farm manager } & 1 & <1 \\ \text { Service } & 25 & 9 \\ \text { Yes } & 92 & 31 \\ \text { No } & 193 & 66 \\ \text { Can't determine } & 8 & 3 \\ 1 \text { year or less } & 60 & 21 \\ 2-5 \text { years } & 81 & 28 \\ 6 \text {-10 years } & 60 & 21 \\ \text { More than 10 years } & 83 & 29 \\ \text { 18-25 } & 40 & 13 \\ 26-30 & 44 & 14 \\ 31-35 & 38 & 12 \\ 36-40 & 33 & 10 \\ 41-45 & 19 & 6 \\ 46-50 & 31 & 10 \\ 51-55 & 25 & 8 \\ 56-60 & 35 & 11 \\ 61-65 & 26 & 8 \\ 66-70 & 12 & 4 \\ \text { >70 } & 14 & 4\end{array}$

$<8$

8-11

H.S. Diploma

Post H.S. ed., not college

Some college

Bachelor degree

College beyond bachelor degree Ph.D., MD, DDS, etc.
N $\%$

$76 \quad 46$

$10 \quad 6$

$48 \quad 29$ 
Table 1. (Continued)

\begin{tabular}{|c|c|c|c|}
\hline QUESTION & & $\mathbf{N}$ & $\%$ \\
\hline Spouse employed & $\begin{array}{l}\text { Full-time } \\
\text { Part-time } \\
\text { No }\end{array}$ & $\begin{array}{r}166 \\
21 \\
122\end{array}$ & $\begin{array}{r}54 \\
7 \\
40\end{array}$ \\
\hline Spouse looking for job & $\begin{array}{l}\text { Yes } \\
\text { No }\end{array}$ & $\begin{array}{r}18 \\
105\end{array}$ & $\begin{array}{l}15 \\
85\end{array}$ \\
\hline Why spouse not looking for job & $\begin{array}{l}\text { Retired } \\
\text { Disabled } \\
\text { Housewife } \\
\text { Young children } \\
\text { Student } \\
\text { Other }\end{array}$ & $\begin{array}{r}33 \\
10 \\
34 \\
8 \\
5 \\
12\end{array}$ & $\begin{array}{r}32 \\
10 \\
33 \\
8 \\
5 \\
12\end{array}$ \\
\hline Spouse occupation & $\begin{array}{l}\text { Professional/technical } \\
\text { Manager/administrator } \\
\text { Sales } \\
\text { Clerical } \\
\text { Craftsmen/foremen } \\
\text { Operative } \\
\text { Transportation } \\
\text { operative } \\
\text { Laborer } \\
\text { Service } \\
\text { Private household } \\
\quad \text { worker }\end{array}$ & $\begin{array}{r}62 \\
21 \\
17 \\
18 \\
23 \\
25 \\
\\
6 \\
9 \\
16 \\
\\
1\end{array}$ & $\begin{array}{r}31 \\
11 \\
9 \\
9 \\
12 \\
13 \\
\\
3 \\
4 \\
8 \\
\end{array}$ \\
\hline Spouse years at current job & $\begin{array}{l}1 \text { year or less } \\
2-5 \text { years } \\
6-10 \text { years } \\
\text { More than } 10 \text { years }\end{array}$ & $\begin{array}{l}30 \\
53 \\
32 \\
70\end{array}$ & $\begin{array}{l}16 \\
29 \\
17 \\
38\end{array}$ \\
\hline $\begin{array}{l}\text { Male occupation } \\
\quad \text { (respondents and spouses) }\end{array}$ & $\begin{array}{l}\text { White collar } \\
\text { Blue collar } \\
\text { Service }\end{array}$ & $\begin{array}{r}141 \\
116 \\
26\end{array}$ & $\begin{array}{r}50 \\
41 \\
9\end{array}$ \\
\hline $\begin{array}{l}\text { Female occupation } \\
\text { (respondents and spouses) }\end{array}$ & $\begin{array}{l}\text { White collar } \\
\text { Blue collar } \\
\text { Service }\end{array}$ & $\begin{array}{r}167 \\
21 \\
16\end{array}$ & $\begin{array}{r}82 \\
10 \\
8\end{array}$ \\
\hline $\begin{array}{l}\text { Male occupation part } \\
\text { of energy industry }\end{array}$ & $\begin{array}{l}\text { Yes } \\
\text { No }\end{array}$ & $\begin{array}{l}127 \\
154\end{array}$ & $\begin{array}{l}45 \\
55\end{array}$ \\
\hline $\begin{array}{l}\text { Female occupation part } \\
\text { of energy industry }\end{array}$ & $\begin{array}{l}\text { Yes } \\
\text { No }\end{array}$ & $\begin{array}{r}30 \\
167\end{array}$ & $\begin{array}{l}15 \\
85\end{array}$ \\
\hline
\end{tabular}


Income (annual household)

$\begin{array}{lrr}<\$ 7,000 & 47 & 10 \\ \$ 7,000-11,000 & 55 & 12 \\ \$ 11,000-15,000 & 57 & 12 \\ \$ 15,001-20,000 & 75 & 16 \\ \$ 20,001-30,000 & 95 & 20 \\ \$ 30,001-40,000 & 48 & 10 \\ >\$ 40,000 & 39 & 8 \\ \text { Refused } & 34 & 7 \\ \text { Don't know } & 26 & 5\end{array}$

Despite efforts to avoid a sex differential in the sample by interviewing only during evenings and weekends, 61 percent of the sample was female. On the basis of census reports for 1970, 55 percent of the sample should have been female. Although females are over-represented, and the difference between the obtained 61 percent and the expected 55 percent is a statistically significant difference, this raises no serious questions about the integrity of the sample. In most telephone surveys women are slightly over-represented, but not enough to alter conclusions. In cases where male/female differences are large, we have presented our results broken down by sex.

The age of respondents ranged from 18 to 93 years with the mean (average) being 45 years. Fifteen percent of the respondents were 18 to 25 and 22 percent were over 60 years old.

Nearly three-fourths (71 percent) of the respondents live in houses as opposed to other types of dwellings; however, more people in this area live in mobile homes (16 percent) than apartments (11 percent) or duplexes (2 percent). Seventy-seven percent own their home and 22 percent rent. Renters pay an average of about $\$ 250$ per month.

Two-thirds of the respondents were married, 14 percent were single, 9 percent separated or divorced, and 10 percent were widowed. The mean number of children per household was .88 with more than one-half the households (52 percent) childless. Eleven percent of the households contained one or more relatives while 6 percent included one or more unrelated persons. The total number of persons per household averaged 2.75, with the two-person household being most common.

The average length of time respondents had lived within their county of residence was 26 years, while the length of residence in their state ave raged 34 years. Fifty percent of the sample have lived in their state of residence for more than 30 years.

There was a wide range in educational attainment among the respondents. Twenty percent of the sample had less than a high school education while 31 percent had received a high school diploma. More than a quarter of the respondents (27 percent) had attended some college or had received a bachelor's degree, and a hefty 18 percent had attended college at the graduate level. Altogether, 45 percent of the sample had received at least some college education. This rather high proportion of college attenders no doubt reflects the presence of WVU in the Monongalia area. 
Sixty percent of the respondents were employed, but only 15 percent of those not employed were looking for a job. Sixty-one percent of the sample was female, which may explain the high proportion of respondents who were not in the labor force. Of those who were not employed or looking for work, 29 percent were housewives and 46 percent were retired. In other words, 16 percent of the total sample consisted of retired persons.

Occupation was asked of respondents and was then disaggregated by sex. A high proportion of residents were employed in white collar occupations and there was a statistically significant difference between males and females by occupation (Figure 2). Two-thirds of the males were employed in white collar jobs, 28 percent in blue collar, and 6 percent in service jobs. Among females, 82 percent were in white collar jobs, 13 percent in blue collar, and 5 percent in service occupations.

Figure 3.

Energy-related occupation by sex

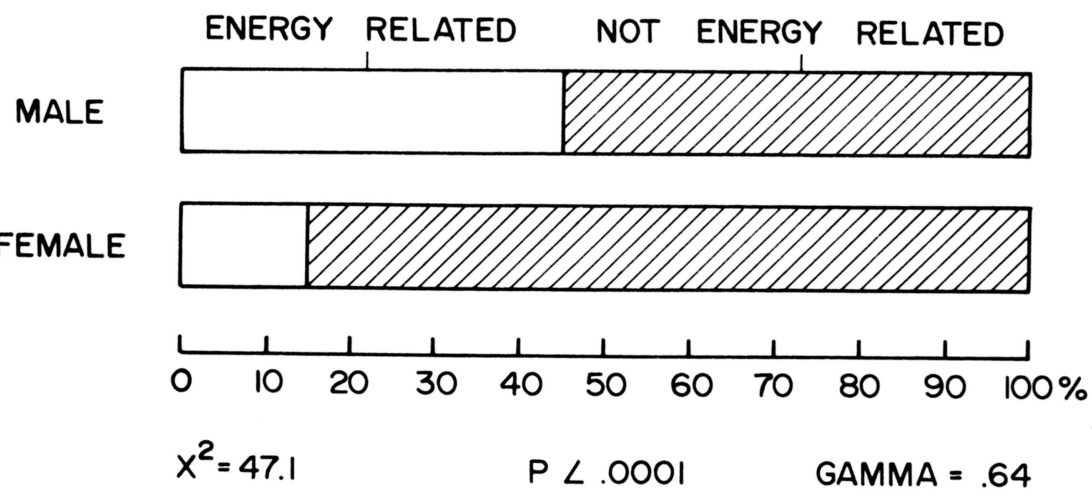

Respondents were asked whether they were employed in an occupation related to the energy industry. Significantly more males than females said yes (Figure 3 ). Forty-five percent of the males versus 15 percent of the females said their job was energy-related.

Although income is generally a difficult item to obtain information about in interviews, only 7 percent of the sample refused to answer this question. Thirty-eight percent of the respondents reported annual household income of $\$ 15,000$ or less, 41 percent said $\$ 15,001$ to $\$ 30,000$, and 21 percent reported above $\$ 30,000$. Interestingly, there was a statistically significant difference in reported incomes by sex of respondent. Although interviewers asked for household income and although most respondents were married, females reported significantly lower household income than males (Figure 4).

How can we characterize our sample? The Monongalia area has a population which reflects several major influences. As the home of a large 
Figure 4.

Household income by sex

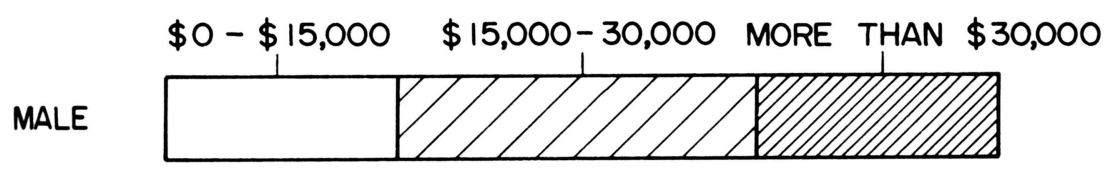

FEMALE
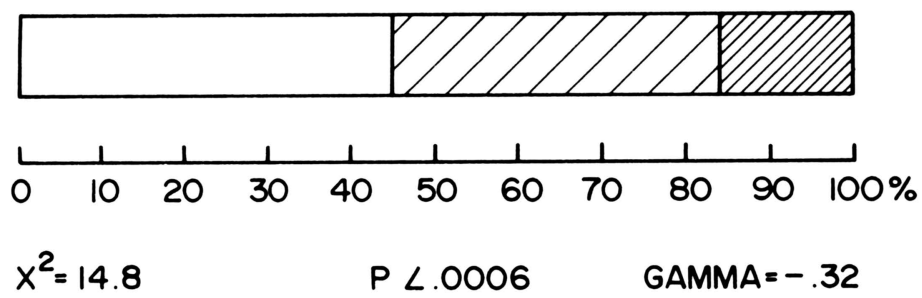

deep-mining industry and West Virginia University, the area has a mix of blue collar and white collar occupations. As an area that has experienced neither recent rapid growth nor decline, the population is well-rooted: more than 70 percent of the non-student portion of the sample has lived in this state more than two decades and in their county of current residence more than ten years. This rootedness is further reflected in the fact that more than three-fourths of the respondents own their dwellings. A fairly large proportion of the sample is not working (39 percent), which is not surprising in a sample comprising 61 percent females and 22 percent over 60 years of age. The high proportion of older respondents, who are predominantly female, is typical of an area which has a regional medical center and which has suffered out-migration in fairly recent times.

\section{ASSESSMENTS OF THE QUALITY OF LIFE IN THE MONONGALIA AREA}

Social scientists try to assess the effects of energy development and other large-scale changes on local communities by measuring quality of life. There are two main approaches to measuring quality of life. The objective approach is based on a score given to a community in comparison with other communities. The score is a combination of objective measures, including such factors as hospital beds per capita, average income, unemployment rate, and number of community organizations. This approach assumes that the investigator knows how important each factor is, that he can find data to measure each factor, and that he knows how much weight to give each factor in an overall score. Many important values, such as community satisfaction and neighborliness, tend to be left out. The perceived quality of life, or subjective approach, avoids these problems by asking a representative sample of local citizens direct questions about the quality of life. Using this approach it is assumed that citizens can accurately relate what they like and dislike about 
their community. This is not as simple as it appears, since people tend to rationalize. The quality of life as measured by objective standards could be very poor and still the residents might rate it high.

Although subjective measures probably rely too much on the limited ability to give an accurate evaluation of circumstances, they do have the advantage of allowing the concerns of the public to be recognized, with or without the concurrence of experts. Accordingly, this research uses the subjective approach to quality of life assessment, in the hope that most of the "objective problems" of the local area will be recognized by respondents.

The distributions of these quality of life measures appear in Table 2. The first set of quality of life questions asks the respondent for an overall assessment of preference for this locale. The first of these is "pride in the area." When asked how proud they were of the local area, nearly nine-tenths of the respondents said they were proud or very proud while only 11 percent were not very proud of the area.

Table 2.

Attitudes Toward the Local Area:

Monongalia Area Survey, 1981.

\begin{tabular}{lrr}
\hline QUESTION & $\mathbf{N}$ & $\%$ \\
\hline How proud of local area & 207 & 43 \\
Very proud & 217 & 45 \\
Proud & 53 & 11 \\
Not very proud & 8 & 2 \\
Don't know & & \\
Is this a good place to raise children & 399 & 82 \\
Yes & 52 & 11 \\
Somewhat & 29 & 6 \\
No & 4 & 1 \\
Don't know & & \\
Is this a good place to retire to & 327 & 68 \\
Yes & 44 & 9 \\
Somewhat & 106 & 22 \\
No & 7 & 1 \\
Don't know & & \\
Is this area improving, staying same or going downhill & 259 & 53 \\
Improving & 151 & 31 \\
Staying same & 63 & 13 \\
Going downhill & 12 & 2 \\
Don't know & & \\
Where do you think you will be living in 5 years & 283 & 59 \\
Same home & 74 & 15 \\
Another home in this area & 99 & 21 \\
Outside local area & 24 & 5 \\
No idea & &
\end{tabular}


Where would you prefer to be living in 5 years

Same home

Another home in this area

164

25

Outside local area

No idea

92

Would you like to see the population of this area:

Grow fast

Grow slowly

$59 \quad 12$

Stay the same

$315 \quad 65$

Decline

Don't know

$88 \quad 18$

143

$7 \quad 1$

What do you like most about this area

Rural atmosphere/peacefulness

$142 \quad 31$

People (friendly/helpful)

$107 \quad 23$

WVU

$\begin{array}{ll}70 & 15\end{array}$

Convenience of city while living in country

$35 \quad 8$

Mountains/scenery

164

Recreation

153

"Have always lived here"

143

Employment opportunities

"Nothing"

Hospitals

Clean

Other

123

$6 \quad 1$

$5 \quad 1$

51

$32 \quad 7$

What do you think is the one biggest problem in the area

Roads

Lack employment opportunities

$58 \quad 12$

Parking/traffic

$54 \quad 11$

Housing

Crime/vandalism

Pollution/litter

Lack of industry

Lack of planning

WVU

Local government

Poor comm unity relations

Schools

Lack recreation facilities

Utilities

Lack of social services

Strip mining

Prospect of these industries

*Other

Don't know

$45 \quad 9$

$23 \quad 5$

235

$23 \quad 5$

235

204

204

184

184

112

92

61

41

41

41

$78 \quad 16$

429

*"Other" included: "nothing"-no problems here; lack of restaurants; poor shopping; inflation; dogs; unionized coal miners; citizen apathy; lack of entertainment places.

(continued) 
What is the first thing you would change in the area if you had the chance

$\begin{array}{lrr}\text { Roads } & 67 & 14 \\ \text { Schools } & 29 & 6 \\ \text { Pollution/litter/dirty } & 29 & 6 \\ \text { Lack of recreation facilities } & 24 & 5 \\ \text { Housing } & 23 & 5 \\ \text { Parking/traffic } & 23 & 5 \\ \text { Lack of employment opportunities } & 19 & 4 \\ \text { Local government } & 17 & 4 \\ \text { Lack of planning } & 17 & 4 \\ \text { Lack of industries } & 14 & 3 \\ \text { WVU } & 14 & 3 \\ \text { Crime } & 11 & 2 \\ \text { Utilities } & 6 & 1 \\ \text { Lack of social services } & 5 & 1 \\ \text { Poor community relations } & 4 & 1 \\ \text { Prospect of these industries } & 3 & 1 \\ \text { Strip mining } & 2 & <1 \\ \text { *Other } & 100 & 21 \\ \text { Don't know } & 75 & 16\end{array}$

*"Other" included responses such as: beautify downtown; aid for elderly (especially housing); more shopping facilities, more restaurants (especially late night); and "nothing"-wouldn't change anything.

Do you think, in this area, that air pollution is:

No problem

Small problem

Moderate problem

$149 \quad 31$

Big problem

Don't know

Do you think water pollution is:

No problem

Small problem

Moderate problem

$170 \quad 35$

Big problem

Don't know

14430

184

Do you think traffic congestion is:

No problem

Small problem

245

Moderate problem

$58 \quad 12$

Big problem

$140 \quad 29$

Don't know

$257 \quad 53$

61

Do you think land reclamation is:

No problem

$64 \quad 13$

Small problem

10522

Moderate problem

$172 \quad 36$

Big problem

$88 \quad 18$

Don't know

$56 \quad 12$


Eighty-two percent thought the area is a good place to raise children, and more than two-thirds thought it is a good place to retire. Fifty-three percent said they thought the area is improving, 31 percent said it is staying the same, and only 13 percent said it is going downhill.

Respondents were asked where they thought they would be living five years from now, and nearly three-quarters said they thought they would still be living in the area (59 percent thought they would be living in the same home and 15 percent thought they would be living in another home in this area). When asked where they would prefer to be living in five years, 41 percent said they would like to remain in their same home, 23 percent would prefer to be living in another home in the area, and 34 percent would prefer to be living outside the local area.

More residents would prefer to move elsewhere (34 percent) than expect to move elsewhere (21 percent), and more would prefer to change housing in the local area (23 percent) than expect to do so (15 percent). This shows that not everyone who lives here really wants to. Just as important, it demonstrates some dissatisfaction with housing, which, as we shall see later, generally is perceived as a problem in the area.

Most of the people interviewed said they would like to see the population of the area grow slowly (65 percent), while 12 percent would like to see it grow fast, 18 percent wanted the population to remain the same and 3 percent would like to see it decline.

The features that respondents liked most about the area were the rural atmosphere and peacefulness (31 percent), the people (23 percent), and the availability of the University (15 percent). Interestingly, 3 percent of the sample said what they liked most about the area is the fact that they have always lived here and it is home to them.

What do people see as major problems in the area? What factors detract from the local quality of life? First, respondents were asked what they thought were the biggest problems in the area. Their answers in descending orderinadequate roads, lack of employment opportunities, and parking and traffic congestion. When asked what they would change if the choice were up to them, respondents said they would do something about roads, schools, and pollution and litter, in that order.

For the purpose of monitoring changes in attitudes after industries have been developed in Monongalia County, respondents were asked if they perceived a problem in a number of areas that the authors felt would be affected by industrial development. When asked if they thought air pollution was a problem in the area, 16 percent said they thought it was a big problem, whereas 15 percent said it was not a problem. The majority felt air pollution was a small or moderate problem in the area. However, females thought it was a problem significantly more often than did males (Figure 5).

In a survey conducted in the mid-1960s, 47 percent of Morgantown heads of households sampled said they were bothered "somewhat" by air pollution and an additional 5 percent were bothered "quite a lot" (Lawyer, 1966). This seems to indicate that air pollution is seen as more of a problem now than it was 15 years ago. Whatever actual air pollution levels are or have been, the tendency to see it as a problem has increased in recent years. Thus the Monongalia area is probably part of a well-documented national trend toward rising concern about the environment (Catton and Dunlap, 1978; CEQ et al., 1980). 
Figure 5.

Perceived problem of air pollution by sex

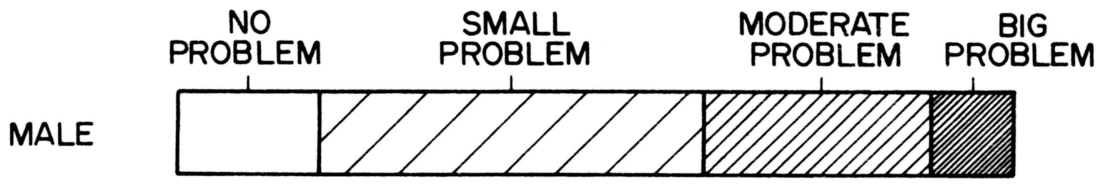

FEMALE
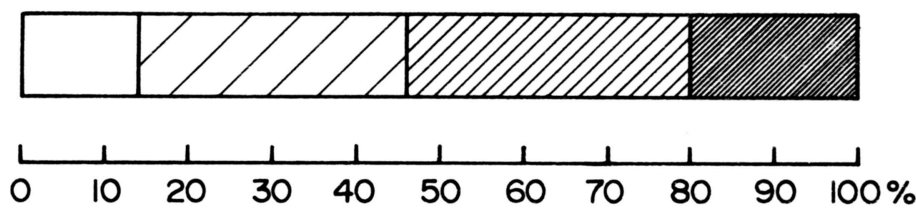

$x^{2}=17.7$

$P<.0005$

GAMMA $=.26$

Thirty percent thought water pollution was a big problem in the area and 11 percent said it was not a problem. More than one-half of the respondents felt that traffic congestion was a big problem, but only 5 percent saw no problem with traffic. Again, females thought of traffic congestion as a problem significantly more often than did males (Figure 6 ). Land reclamation was perceived as a big problem by 18 percent and not as a problem by 13 percent of the residents contacted.

In the previous section of this publication the authors looked at the demographic characteristics of the MAS sample and concluded that the area population had strong roots, both by virtue of length of residency and the high level of home ownership. Roots are also evident in attitudes toward the Monongalia area: residents see the a rea as a good place to retire and to raise children; they are proud of the area, and feel that it is improving. Most respondents hope to remain in the area. To people who live in the area, it comes as no surprise that the peaceful, friendly, rural atmosphere is highly valued. The biggest problems, according to respondents, are roads, unemployment, and parking and traffic. Most of the sample regarded air and water pollution as small or moderate problems, but few saw pollution as no problem at all.

The authors draw this portrait of the Monongalia area, because industrial development affects not only the economics of an a rea; it also affects values. New industry could bring in money and jobs, but it could also destroy some of the features that make residents proud of the area, and it could aggravate existing problems. A simple dollars-and-cents approach to industrial development-so typical in the past-does nothing to ensure high quality of life. 


\section{ASSESSMENTS OF LOCAL SERVICES AND FACILITIES}

Respondents residing in West Virginia were asked to indicate their level of satisfaction with local services and facilities by indicating whether they were "very satisfied," "satisfied," or "dissatisfied" with each of a number of specified public services and facilities (Pennsylvania residents were excluded from this portion of the analysis). Figure 7 illustrates the level of satisfaction with these services reported by respondents.

Although respondents living in different sections of the study area likely evaluated the services of their immediate community, and therefore, these results reflect satisfaction with various service units (e.g., Morgantown police force versus Westover or Star City police forces), the responses are reported together as overall satisfaction with services in the Monongalia area. The service with which the respondents reported the most satisfaction was ambulance service, with which only 4 percent were dissatisfied (59 percent were satisfied and 36 percent were very satisfied). Next were health services, with which only 7 percent were dissatisfied (66 percent were satisfied and 26 percent were very satisfied), and fire protection with which only 9 percent were dissatisfied (69 percent were satisfied and 22 percent were very satisfied).

The degree of satisfaction with several aspects of public schools was also ascertained from the survey. School bus service was one of the services with which respondents were most satisfied. While only 15 percent were very satisfied, 73 percent were satisfied with school bus service and only 12 percent were dissatisfied. Respondents were also generally satisfied with public school staff; nevertheless, almost one-quarter of the respondents evaluated school staff as unsatisfactory. Local residents were less satisfied with public school curriculum and facilities than with teaching staff. Twenty-eight percent of the people questioned were dissatisfied with school curricula, while 32

Figure 6.

Perceived problem of traffic congestion by sex

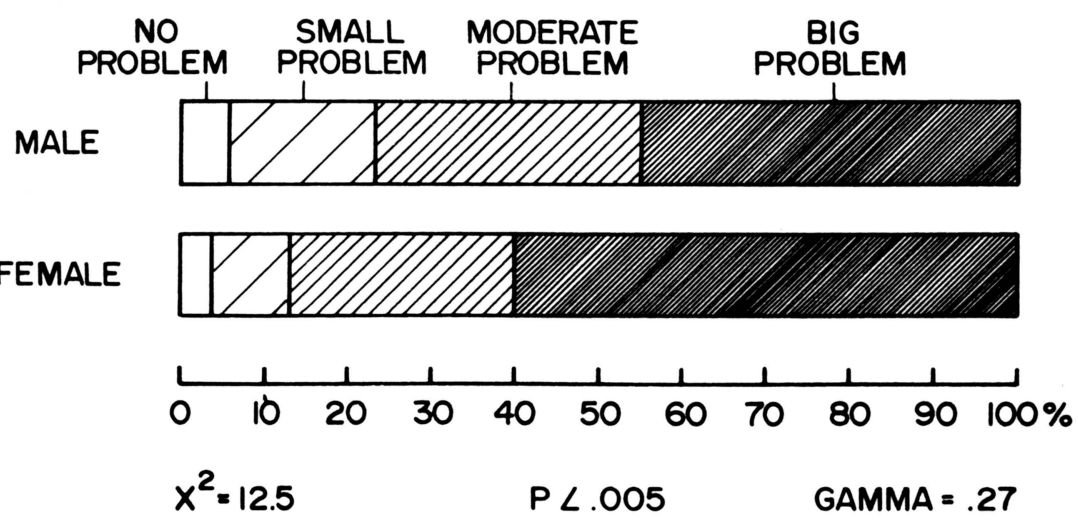




\section{Figure 7. \\ Respondent satisfaction with local services}

Ambulance service

health SERvice

FIRE PROTECTION

SCHOOL BUS SERVICE

GARBAGE COLLECTION

PUblic WATER SERVICE

SERVICES FOR SENIOR CITIZENS

PUblic bus SERVICE

PUBlic SCHOOL STAFF

OUTDOOR RECREATION

LOCAL SHOPPING

PUBLIC SCHOOL

CURRICULUM

PUBLIC SCHOOL FACILITIES

Public SEWAGE

LAW ENFORCEMENT

CITY GOVERNMENT

INDOOR RECREATION

HOUSING QUALITY

HOUSING AVAILABILITY

ROAD MAINTENANCE

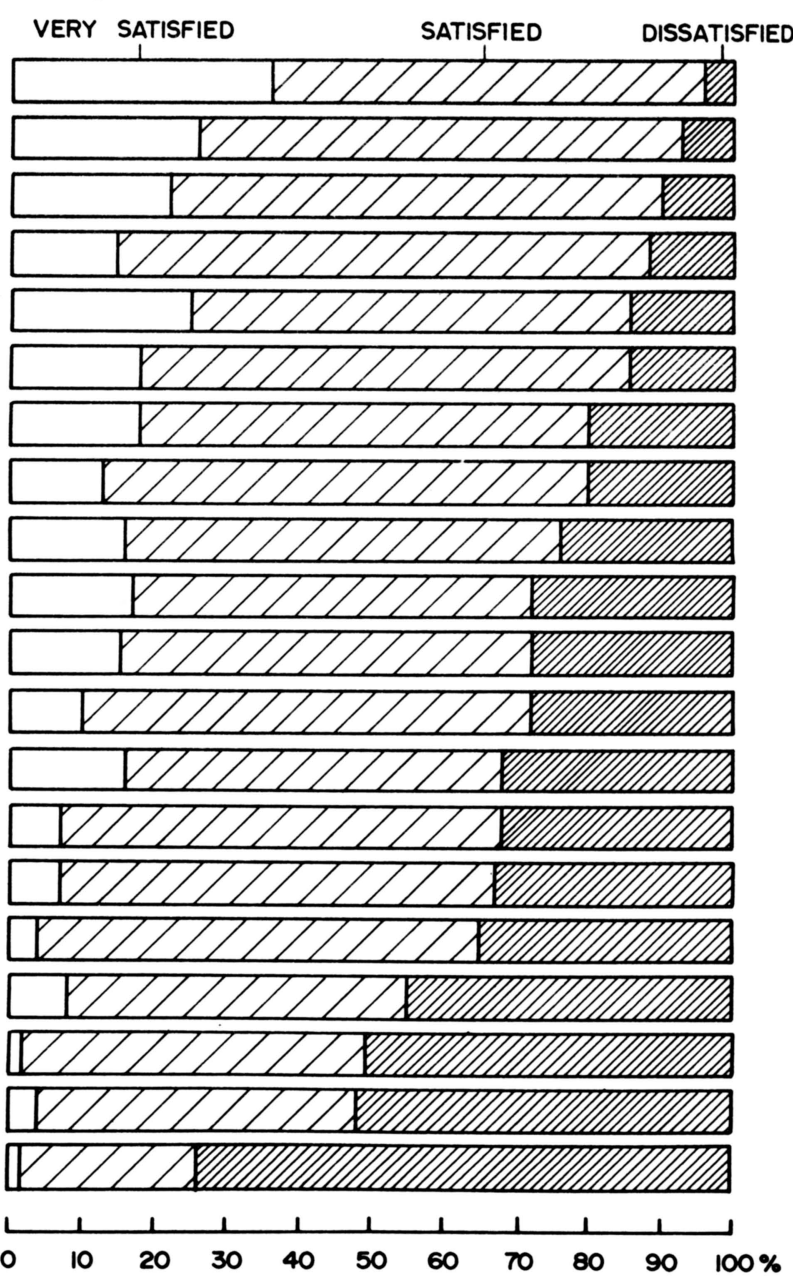

percent were dissatisfied with public school facilities. Recalling the responses to the question discussed earlier, "What is the first thing you would change in the area if you had the chance?" "schools" was the second most frequent answer, offered by 6 percent of the sample. It appears that the aspects of public schools which local residents would most like to see changed are, first, the school facilities and then, the curriculum. 
Local residents were generally satisfied with garbage collection service and public water service. Only 15 percent judged each of these services to be unsatisfactory. Public sewage, in contrast, was evaluated as unsatisfactory by one-third of the respondents and as very satisfactory by 7 percent of the sample (60 percent were satisfied).

Most residents ( 80 percent) felt that services for senior citizens were satisfactory or very satisfactory in this area, with one-fifth of the sample being dissatisfied with senior citizen services. Twenty percent of the residents questioned were also dissatisfied with public bus service with only 13 percent rating bus service as very satisfactory and about two-thirds rating it as satisfactory.

One-third of the residents contacted were dissatisfied with local law enforcement. Only 7 percent felt law enforcement was very satisfactory in this area, while 60 percent were satisfied with th is public service. Correspondingly, "crime and vandalism" was the fourth most frequent response to the previously discussed question: "What do you think is the one biggest problem in the area?"

More than one-third of the respondents were dissatisfied with city government (35 percent) while 61 percent were satisfied and only 4 percent were very satisfied. There was a statistically significant difference in satisfaction with city government by sex, however, with males being significantly less satisfied with the local government than females. Males and females also differed significantly on their satisfaction with local shopping. Females reported more dissatisfaction with local shopping than did males.

Respondents were generally satisfied with outdoor recreation facilities, even though more than one-quarter rated outdoor recreation as unsatisfactory (28 percent). However, local residents were much less satisfied with indoor recreation facilities. Forty-five percent felt that indoor recreation was unsatisfactory, 47 percent were satisfied, and only 8 percent were very satisfied with indoor recreation facilities in the area. Correspondingly, "lack of recreation facilities" was the fourth most frequent response to the question "What is the first thing you would change in the area?" It appears that it is not the outdoor aspect of recreation local residents are concerned with, but rather the need for more indoor recreation facilities.

Few local residents are pleased with local housing. More than one-half of them evaluated both housing quality and housing availability as unsatisfactory. Only 2 percent were very satisfied with housing quality (46 percent were satisfied and 51 percent were dissatisfied) and only 4 percent were very satisfied with housing availability (44 percent were satisfied and 52 percent were dissatisfied).

Respondents were least satisfied with road maintenance-nearly threequarters of the sample were dissatisfied, 24 percent were satisfied, and less than 2 percent were very satisfied with road maintenance. A pilot survey conducted in the summer of 1980 had also shown much dissatisfaction with road maintenance which the authors thought might be attributed to the construction of the new roads to the recently constructed WVU stadium. However, these roads were completed by the time of the Monongalia Area Survey so our results show that dissatisfaction with road maintenance in this area does not reflect construction inconveniences. Residents are apparently not happy with general maintenance of streets and highways. 
In sum, the local services and facilities viewed most favorably by local residents are ambulance service, health services, and fire protection. Respondents were generally dissatisfied with indoor recreation facilities, housing availability and quality, and road maintenance. If the population of this area continues to increase at the current rate, or if industries begin to locate in this area and stimulate more rapid population growth, it is apparent from these survey results which local services and facilities will require the most immediate attention: road maintenance, housing, and indoor recreation facilities.

\section{PURCHASING PATTERNS OF TOWNSPEOPLE AND STUDENTS}

If government and business leaders are to understand the effects of industrial development in the Monongalia area, they must first understand where area residents spend their money for goods and services. In order to determine how much of the household's income is returned to the local economy, residents were asked to estimate what proportion of their household income was spent within Monongalia County. Respondents were asked about their household purchases in five major areas of expenditure. Assuming that nearly all residents spend money for food and housing with in the locality, the interviews focused on the categories of clothes, automobile repair and maintenance, gasoline, vehicle purchases, and appliances and furniture. Other goods and services (e.g., household and personal purchases outside of these categories) were ignored because of estimation difficulties for small figures.

Respondents were first asked, "Of all the money your household spent on clothes last year, what percentage would you say you spent within Monongalia County?" (Respondents residing outside of this county-in Point Marion, Pa.-were excluded from this portion of the interview.) Responses were:

\begin{tabular}{lrr}
\hline $\begin{array}{l}\text { Percent of household clothing } \\
\text { expenditures within } \\
\text { Monongalia County }\end{array}$ & $\mathrm{N}$ & $\%$ \\
\hline 0 & 11 & 3 \\
$1-25$ & 16 & 4 \\
$26-50$ & 48 & 13 \\
$51-75$ & 41 & 11 \\
$76-99$ & 97 & 26 \\
100 & 166 & 44 \\
\hline
\end{tabular}

While over 40 percent of the households reported buying all of their clothing within the county, most respondents bought at least some of their clothing outside the county last year, and 20 percent did at least one-half of their clothes shopping outside the county. Competition from nearby retail markets (Washingtọn and Pittsburgh, Pa., and Fairmont and Clarksburg, W. Va.) probably account for the large proportion of clothing dollars spent outside Monongalia County. 
Respondents were then asked what percentage of the money they spent on automobile repair and maintenance in the last year was spent in Monongalia County? Responses follow:

\begin{tabular}{lrr}
\hline $\begin{array}{l}\text { Percent of household } \\
\text { auto repair and maintenance } \\
\text { expenditures within } \\
\text { Monongalia County }\end{array}$ & $\mathrm{N}$ & \\
\hline 0 & 40 & \\
$1-25$ & 32 & 10 \\
$26-50$ & 24 & 8 \\
$51-75$ & 7 & 6 \\
$76-99$ & 22 & 2 \\
100 & 295 & 70 \\
\hline
\end{tabular}

Note that most local residents (70 percent) have all of their automobile repair and maintenance done locally. Less than one-quarter of the residents (23 percent) report making one-half or more of their auto repair expenditures outside of Monongalia County.

Respondents were asked what proportion of the money their household spent on gasoline last year was spent within the county? They reported the following:

\begin{tabular}{lrr}
\hline & & \\
\hline $\begin{array}{l}\text { Percent of household } \\
\text { gasoline expenditures }\end{array}$ & $\mathrm{N}$ & $\%$ \\
in Monongalia County & 11 & 3 \\
0 & 17 & 4 \\
$1-25$ & 21 & 5 \\
$26-50$ & 60 & 14 \\
$51-75$ & 171 & 40 \\
$76-99$ & 148 & 35 \\
100 & & \\
\hline
\end{tabular}

Although only 35 percent of the respondents reported buying all of their gasoline within the county, a small proportion (24 percent) reported making a quarter or more of their gasoline purchases outside the county. Most families travel and therefore buy gasoline outside the local area at least once a year; therefore many respondents reported buying a small portion of their gasoline in another area. Only 11 percent bought one-half or more of their household's gasoline outside Monongalia County, while three-quarters of the respondents bought at least 75 percent of their gasoline in the local area.

Next, respondents were asked, "Of all the money your household spent to buy cars and trucks in the last five years, what percentage did you spend in Monongalia County?" 


\begin{tabular}{lrr}
\hline $\begin{array}{l}\text { Percent of household } \\
\text { automobile purchase } \\
\text { expenditures in }\end{array}$ & & \\
Monongalia County & $\mathrm{N}$ & $\%$ \\
\hline 0 & 63 & 18 \\
$1-25$ & 15 & 4 \\
$26-50$ & 33 & 9 \\
$51-75$ & 14 & 4 \\
$76-99$ & 13 & 4 \\
100 & 213 & 61 \\
\hline
\end{tabular}

While most local families (61 percent) bought all of their automobiles within the local area, almost one-third (32 percent) bought one-half or more of their household's cars and trucks outside the county and 18 percent did not buy any automobiles within the local area.

When residents were asked where they bought their appliances and furniture during the last five years, they offered the following responses:

\begin{tabular}{lcr}
\hline $\begin{array}{l}\text { Percent of household } \\
\text { appliance and furniture } \\
\text { expenditures within } \\
\text { Monongalia County }\end{array}$ & $\mathrm{N}$ & $\%$ \\
\hline 0 & 26 & 6 \\
$1-25$ & 32 & 8 \\
$26-50$ & 33 & 8 \\
$51-75$ & 20 & 5 \\
$76-99$ & 45 & 11 \\
100 & 250 & 62 \\
\hline
\end{tabular}

Again, most residents bought all of their household's appliances and furniture within the county (62 percent). Less than a quarter ( 22 percent) reported buying one-half or more of their appliances outside the local area.

There is a strong tendency to make auto purchases and to seek auto repair in the county. Most residents who buy automobiles locally probably do so in part because local service is available, particularly for repairs covered by warranties. Since few people wish to have their auto serviced or repaired on a while-you-wait basis, most drivers will prefer local garages. Gasoline purchase patterns, in contrast, are heavily influenced by one's customary travel patterns. The more a family drives outside of Monongalia County the more gasoline it must buy outside the county. It is unlikely that purchasing patterns in the area of private vehicles can be influenced much by the behavior of local business.

Clothing expenditures, and to some extent household durables such as appliances and furniture, are in a different class. One can purchase them on a "shopping trip" that is less limited than a shopping trip for an auto or for a muffler repair. Thus, the nature of the local market in comparison to competing markets in Fairmont and Clarksburg, W. Va., and Washington and Pittsburgh, 
$\mathrm{Pa}$., probably influences where people buy. The fact that only about 40 percent of the respondents reported making any appliance or furniture expenditure outside the area probably reflects a desire to have convenient recourse if the product proves unsatisfactory. Clothing purchases are apparently least constrained by distance, and local merchants could at least theoretically capture a larger share of the market.

Whether the figures on proportion of local expenditures are high or low is difficult to say. The authors hope to use these figures as a baseline to monitor changes as industrial development alters the economic face of the Monongalia area.

Local expenditures of WVU students living in private housing were also assessed from the survey in order to determine the economic impact of college students on the local area. Students were asked, How much money did you spend in Monongalia County "last month" (March, 1981) on food, clothes, and entertainment and transportation? The distributions of these expenditures follow:

\begin{tabular}{llr}
\hline $\begin{array}{l}\text { Student dollars spent on food } \\
\text { in Monongalia County } \\
\text { in March, 1981 }\end{array}$ & N & $\%$ \\
\hline $0-50$ & 27 & 13 \\
$51-75$ & 32 & 16 \\
$76-100$ & 55 & 27 \\
$101-150$ & 46 & 22 \\
$151-250$ & 28 & 14 \\
$>250$ & 19 & 9 \\
\hline
\end{tabular}

The median number of dollars spent on food by students was $\$ 100$. More than half of the students (56 percent) reported spending $\$ 100$ or less on food, while 23 percent reported spending more than $\$ 150$.

\begin{tabular}{lrr}
\hline $\begin{array}{l}\text { Student dollars spent on clothes } \\
\text { in Monongalia County in } \\
\text { March, 1981 }\end{array}$ & N & $\%$ \\
\hline 0 & 95 & 43 \\
$1-25$ & 46 & 21 \\
$26-50$ & 39 & 18 \\
$51-100$ & 18 & 8 \\
100 & 21 & 10 \\
\hline
\end{tabular}

Most students interviewed (64 percent) said they spent $\$ 25$ or less on clothing in Monongalia County in March, with 43 percent reporting not spending any money on clothes in the county that month. The median amount of money spent on clothes in one month by students was $\$ 11$. 


\begin{tabular}{lll}
\hline $\begin{array}{l}\text { Student dollars spent on } \\
\text { entertainment and } \\
\text { transportation in } \\
\text { Monongalia County } \\
\text { in March, 1981 }\end{array}$ & & \\
\hline $0-25$ & $\mathrm{~N}$ & $\%$ \\
$26-50$ & 38 & 17 \\
$51-75$ & 55 & 25 \\
$76-100$ & 35 & 16 \\
100 & 52 & 24 \\
\hline
\end{tabular}

The median amount of money spent on entertainment and transportation in Monongalia County was $\$ 65$, with 44 percent of the students reporting spending $\$ 50$ or less on entertainment and transportation in one month. Forty percent said they spent $\$ 51$ to $\$ 100$ on these items, while 17 percent spent more than $\$ 100$ on entertainment and transportation in the month of March.

As these data show, the largest monthly contribution to the local economy by university students (other than for rent) is for food. Entertainment and transportation is the next largest area of contribution by students to the local economy, while students report spending relatively little money within the local area on clothing. The median amount of money university students contributed to the local economy in one month for food, clothing, and entertainment and transportation summed to $\$ 176$.

When this figure is added to money spent on rent (a monthly median of $\$ 138$ per student) the per student expenditure is raised to $\$ 314$, exclusive of miscellaneous expenditures which do not fall into the categories food, rent, clothing, entertainment, and transportation. If this estimate is expanded by multiplying the per student expenditure by the approximate number of fulltime students $(15,567)$ the direct economic input of students is $\$ 4,888,038$ per month, or $\$ 43,992,342$ for an academic year (9 months). This input creates a "multiplier effect" in that every dollar input creates a certain amount of economic activity. For example, when students buy clothes they support clothing store owners, managers and sales people, their families, and other people who supply the clothing store personnel with food, housing, durables, and services. To put it simply, students generate more economic activity than their expenditure levels would indicate. The almost $\$ 44$ million figure understates the case considerably by ignoring the summer months, the multiplier effect, and the enormous impact of West Virginia University itself.

WVU is an economic mainstay of the area, and its existence depends entirely on the patronage of students and the subsidies provided to tuitions in the form of state appropriations, research grants, and philanthropy. In thinking about economic development in the Monongalia area, one should remember that WVU students are a major industry by virtue of their direct and indirect contributions to the local economy. 


\section{ATTITUDES TOWARD ENERGY-RELATED DEVELOPMENTS}

People who listen to the debates that arise when a new industry is proposed in an area will develop impressions about "how people around here feel," but often such impressions are wrong. For one thing, people have strong tendencies to overestimate the extent to which others share their views. Also, most social contacts are with a rather narrow range of other people; in fact, people generally associate with people who believe as they do about many issues. The authors informally observed both pro- and anti-industry residents, and both tended to believe public opinion was on their side. Public opinion can only be assessed by polling a representative sample of the public. To learn how people viewed the proposed industries (a coal liquefaction plant, two coke plants, and an industrial park), the authors first ascertained who had heard of each development (the "recognition factor") and, for those who had heard of a given development, whether respondents favored or opposed each development. In this study respondents were asked about possible impacts of development, how the area might prepare for development, and trade-offs between development and the environment. Their responses are in Table 3.

Table 3.

Attitudes Toward Energy-Related Industries: Monongalia Area Survey, 1981.

\begin{tabular}{lrr}
\hline QUESTION & $\mathbf{N}$ & $\%$ \\
\hline How much heard of Coal Liquefaction Plant & 315 & 65 \\
A lot & 144 & 30 \\
A little & 26 & 5 \\
None & & \\
Favor or oppose Coal Liquefaction Plant & 168 & 36 \\
Strongly favor & 97 & 21 \\
Moderately favor & 20 & 4 \\
Slightly favor & 89 & 19 \\
Undecided & 10 & 2 \\
Slightly oppose & 28 & 6 \\
Moderately oppose & 49 & 11 \\
Strongly oppose & & \\
How much heard of Roundbottom Coke Plant & 214 & 44 \\
A lot & 201 & 41 \\
A little & 70 & 14 \\
None & & \\
Favor or oppose Roundbottom Coke Plant & 69 & 16 \\
Favor strongly & 72 & 17 \\
Favor moderately & 9 & 2 \\
Favor slightly & 124 & 30 \\
Undecided & 12 & 3 \\
Oppose slightly & 48 & 12 \\
Oppose moderately & 85 & 20 \\
Oppose strongly & $($ continued) \\
Pand & &
\end{tabular}


Table 3. (Continued)

How much heard of Sharon Steel Coke Plant

A lot

A little

296

None

$163 \quad 34$

29260

Favor or oppose Sharon Steel Coke Plant

Favor strongly

$41 \quad 20$

Favor moderately

$35 \quad 17$

Favor slightly

115

Undecided

Oppose slightly

Oppose moderately

$80 \quad 39$

42

168

Oppose strongly

$20 \quad 10$

How much heard of Industrial Park

A lot

A little

$46 \quad 10$

$216 \quad 45$

None

$221 \quad 46$

Favor or oppose Industrial Park

Favor strongly

$80 \quad 30$

Favor moderately

$\begin{array}{ll}72 & 27\end{array}$

Favor slightly

Undecided

166

$82 \quad 30$

Oppose slightly

Oppose moderately

Oppose strongly

21

114

62

Perceived benefit of projects for area

Good for area

Neutral

Bad for area

30966

6113

$72 \quad 15$

Don't know

286

Are these projects mostly good or bad for the country

Good

$354 \quad 75$

Conditional

$55 \quad 12$

Bad

Don't know

449

174

Would you vote for or against these projects

For

$296 \quad 63$

Split decision

$50 \quad 11$

Against

9520

Don't know

317 
Who should be responsible for getting community

ready for industries

Federal government

$\begin{array}{rr}62 & 13^{*} \\ 138 & 29^{*} \\ 216 & 46^{*} \\ 128 & 27^{*} \\ 93 & 20^{*} \\ 20 & 4^{*} \\ 26 & 6^{*}\end{array}$

State government

Local/County government

Project companies

Citizens'/civic groups

WVU

Other

Should government encourage coal related industries to

locate here

Yes

$\begin{array}{rr}374 & 77 \\ 45 & 9 \\ 51 & 10 \\ 14 & 3\end{array}$

Conditional

9

Don't know

Specifically, what effects do you think these projects will have on this area

More jobs

$61^{*}$

Pollution (-)

Increase business activity

$29^{*}$

$7315^{*}$

More people: good effect

$296^{*}$

More people: bad effect (-)

$276^{*}$

Housing shortage (-)

Quality of life: decline (-)

Quality of life: improve

Decrease dependence on foreign oil

Boost economy

Crowd schools (-)

Higher wages

Higher prices (-)

Lower fuel prices

No effects expected

Don't know

$194^{*}$

$174^{*}$

$112^{*}$

$112^{*}$

$112^{*}$

$61^{*}$

$51^{*}$

$51^{*}$

$2<1^{\star}$

$51^{*}$

$306^{*}$

Total negative effect responses

21133

Total positive effect responses

"(-)" designates negative effects

What needs to be done to ready the community

for these industries

Planning for growth

More information and education

Planning for environmental health and safety

$15834^{*}$

Roads

Housing

Economic assistance

Schools

Job training

Don't know

$811^{*}$

$7015^{*}$

$6915^{*}$

$5712^{*}$

$1022^{*}$

$7 \quad 2^{*}$

$31^{*}$

$14932^{*}$

(continued) 


\begin{tabular}{lrr}
\hline QUESTION & N & $\%$ \\
\hline Environment versus economy & & \\
Economic growth side & 64 & 13 \\
Middle of the road & 225 & 47 \\
Environment side & 173 & 36 \\
Don't know & 19 & 4 \\
Energy versus environment & & \\
Energy side & 135 & 28 \\
Conditional & 73 & 15 \\
Environment side & 254 & 53 \\
Don't know & 20 & 4 \\
\hline
\end{tabular}

*Percents do not sum to $100 \%$ due to multiple responses.

The industries had been the subject of much controversy in the local media by the time of the survey. Citizen groups had organized to actively oppose the development of two of the proposed industries - the SRC-II Coal Liquefaction Plant and the Roundbottom Coke Plant. The local newspaper listed the news about these two industries as the third top story of the year for 1980 . Therefore, many local residents had probably formed strong opinions about these developments by the time of the survey.

Only 5 percent of the respondents had not heard about the Coal Liquefaction Plant, and 14 percent had not heard about the Roundbottom Coke Plant. Sixty percent of the respondents had not heard about the Sharon Steel Coke Plant proposed for nearby Fairmont, W. Va., and 46 percent had not heard about the Industrial Park proposed for the study area. Male respondents were more aware of all the proposed developments than were female respondents (Figure 8).

The majority of respondents who had heard of the Coal Liquefaction Plant were in favor of it; 61 percent versus 17 percent opposed with 17 percent undecided. Equal numbers of people interviewed favored and opposed the Roundbottom Coke Plant, 35 percent each, while 30 percent were undecided. Of those who had heard about the Sharon Steel Coke Plant, 42 percent favored and 20 percent opposed the plant while 39 percent were undecided. Very few people were opposed to the Industrial Park, only 7 percent, while 63 percent favored and 30 percent did not have an opinion.

The proposed industries were generally favored by respondents. However, female respondents opposed the industries more than males, as depicted in Figure 9.

Two-thirds of the respondents perceived these projects, taken as a whole, as beneficial to the area while 15 percent perceived them as bad for the area. Similarly, three-quarters thought they would be good for the country. Given the opportunity to vote, 63 percent said they would vote for the projects (considered together) compared to 20 percent who said they would vote against them (18 percent were undecided). Again, males said they would vote 
Figure 8.

How much heard about industries by sex

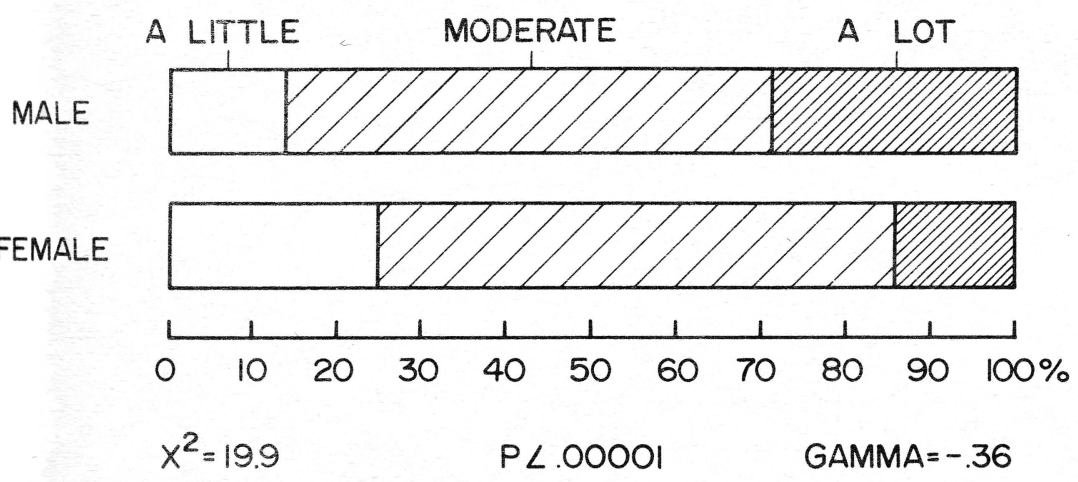

Figure 9.

Favoring versus opposing new industries

by sex

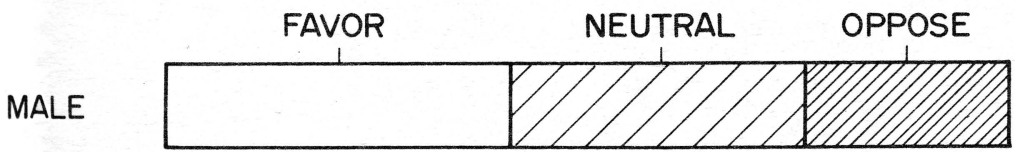

FEMALE
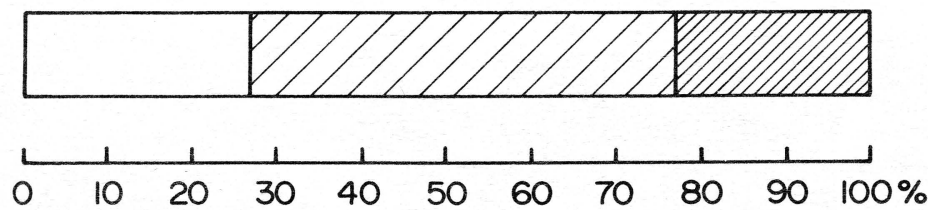

$x^{2}=18.6$

$\mathrm{P} \angle .0001$

GAMMA $=.23$

for the projects significantly more frequently than did females (Figure 10). More than three-fourths of the people questioned (77 percent) thought the government should encourage industries to locate in the area.

Respondents were also asked what effects they thought the projects would have on the area. The most frequent responses were "more jobs" (61 percent); "pollution (29 percent); "increased business activities" (15 percent); and "more people," which 6 percent listed as a positive effect and 6 percent listed as 
Figure 10.

How respondent would vote toward

industries by sex

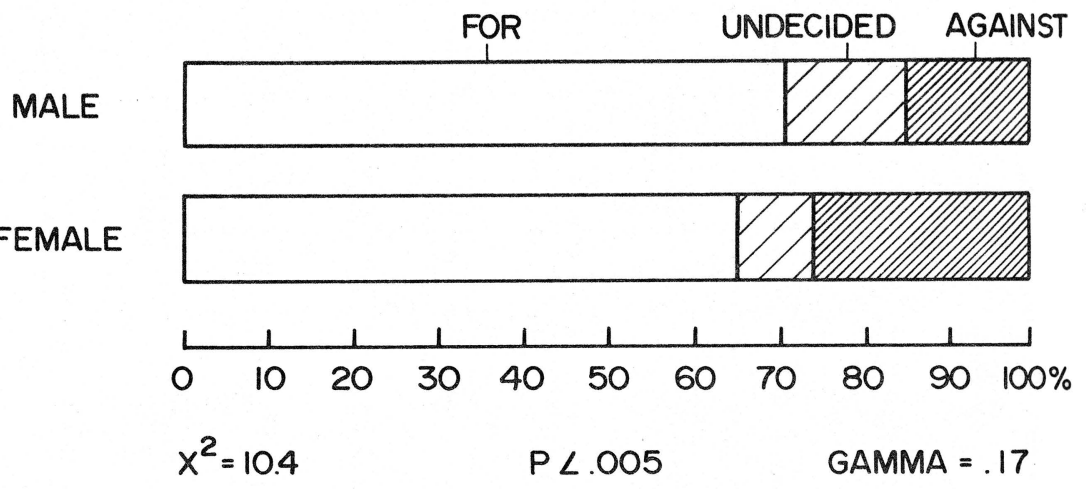

negative. Overall, two-thirds of the expected effects mentioned were positive effects and one-third were negative.

When asked what needs to be done to ready the community for these industries, the most frequent response was "planning for growth" (34 percent). Other needs listed were "more information and education" (17 percent); "planning for environmental health and safety" (15 percent); "roads" (15 percent); and "housing" (12 percent).

Finally, the MAS asked residents for their opinions on energy and economic growth versus the environment so it would be possible to measure the degree of environmentalism in the area. In order to compare environmentalism in the study area with that of a national sample, the questionnaire included two questions that have been asked recently in public opinion polls. The first, which Roper has asked annually since 1973 (CEQ et al., 1980), was: "Are you more on the side of adequate energy or more on the side of protecting the environment?" Responses in this survey were almost two to one on the environmental protection side (53 percent versus 28 percent with 19 percent undecided). In comparison, the 1979 results of the national Roper poll showed fewer people favoring environmental protection than favoring energy adequacy (38 percent versus 43 percent).

Another question concerned the trade-off between economic growth and environmental protection. This question, however, allowed for a middle-ofthe-road response which 47 percent of the sample chose. Thirty-six percent chose the environmental side, and only 13 percent chose economic growth. In contrast, the 1980 national public opinion poll showed fewer people choosing the environment than economic growth (20 percent versus 27 percent while 43 percent were in between).

Nationally, then, people tend to be more concerned with energy development and economic growth than with the environment. In the Monongalia area, though, there appears to be a great deal of environmental 
concern, with residents generally favoring environmental protection over economic growth and energy. At the same time, respondents generally favored the development of energy-related industries and felt strongly than the area will benefit from them and that they should be encouraged to locate in the area. Residents felt that the new industries will bring more jobs and business activity to the area, as well as pollution, and that the positive effects of the industrialization will outweigh the negative effects two to one. Given the opportunity to vote for the industries, two-thirds of the sample said they would support these developments at the polls.

In asking why people support or oppose local industry, it is always difficult to disentangle motives. For instance, many of the local developments considered in the Monongalia area are based on coal. Do residents want coal industry or do they just want industry? How does the desire, or lack of it, for non-polluting industries figure into the equation? To answer these questions, we asked respondents whether they approved of eight different industries. Each industry represents a combination of (1) either coal or non-coal, (2) either polluting or non-polluting, and (3) either local employment opportunities or employment opportunities for outsiders. For example: "a coal mine inspector training school which employs workers from outside the local area" represents a coal-related, non-polluting industry which does not offer local jobs, while "a toothpaste factory which employs local workers" represents a non-coal related, non-polluting industry which will provide local employment opportunities. These three different dichotomous conditions (coal vs. noncoal, polluting vs. clean, and local vs. outside employment) yielded $2 \times 4=8$ combinations that represent the full range of possibilities. To summarize their findings the authors calculated the number of industries of each type which their respondents thought would be "good" or "very good" for the area. It turns out that there is a maximum of $8 / 2=4$ each of coal based, clean, and locally employing industries. Results are presented in Figure 11. Each bar represents the percentage of the industries approved with a given characteristic, with the other factors held constant. Thus, other things being equal, industries which create employment opportunities for local residents are most attractive, since an average of 79.5 percent of the possible four industries won approval. Residents favored 70 percent of the four possible clean industries, and 60.3 percent of the four possible coal industries. Evidently, employment is the first criterion in residents' calculations as to what makes an industry desirable, and the cleanliness of an industry is a second consideration. Evidence indicates that support for an industry on the basis of its relationship to coal is the least important of the three criteria.

\section{WHO FAVORS AND WHO OPPOSES THE PROPOSED INDUSTRIES?}

In an attempt to discover whether people with different socioeconomic characteristics hold different opinions about the proposed new industries, we examined the relationships between the perceived benefit of the industries and selected demographic and attitudinal characteristics of the respondents.

Several hypotheses were derived about these relationships from a pilot study conducted in the summer of 1980 (Stout-Wiegand, Trent, and Smith 
Figure 11.

Approval of hypothetical industries with

varying characteristics: coal vs. non-coal, clean vs. polluting, and local vs. outside employment

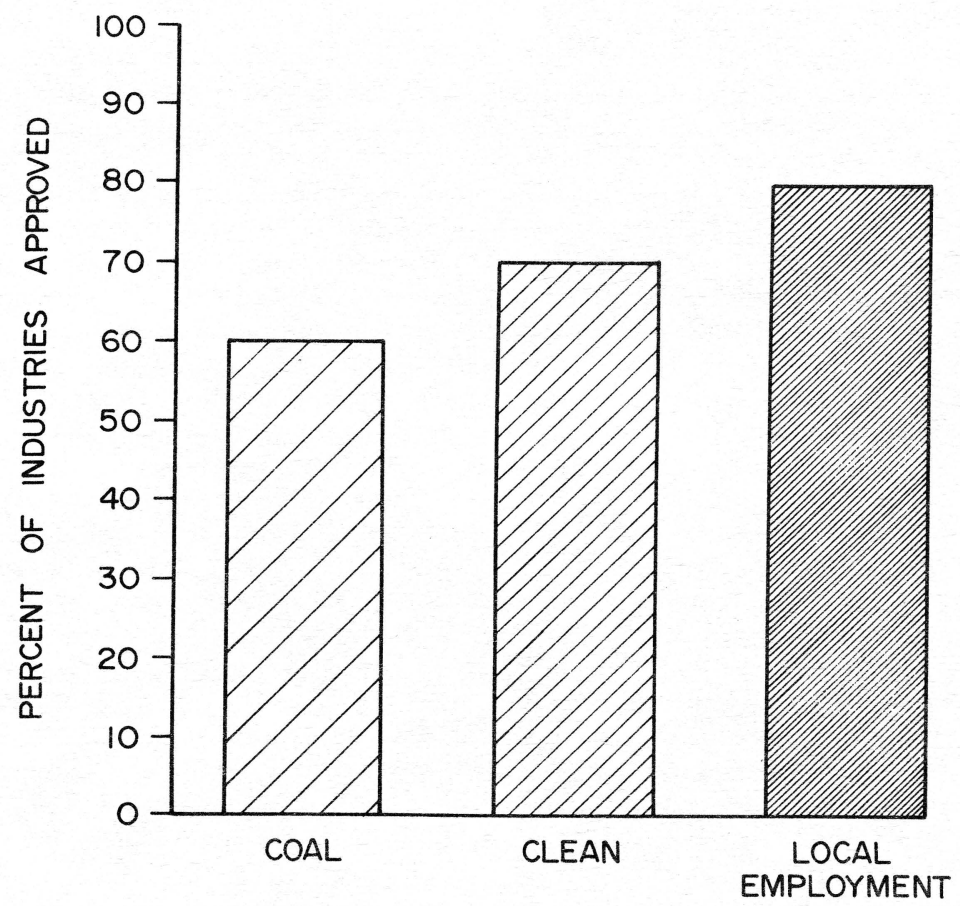

1981) and from the recent research literature on attitudes toward industrial development in rural areas (Summers and Clemente, 1976; Maurer and Napier, 1980).

On the basis of these studies, the authors were able to pose a number of interesting hypotheses to shed light on the question: Who sees local industrial development as beneficial? Specifically, the authors sought to discover whether the perceived benefits of local industrial development are greater among (1) males than females, (2) less educated residents, (3) younger residents, (4) blue collar workers, (5) workers in energy-related industries, and (6) respondents who do not hold pro-environmental attitudes. Furthermore, it was anticipated that perceived benefits would be the link between various objective characteristics of respondents-sex, education, and age, for example-and their attitudes toward industrial development. In other words, if men or less educated respondents are more enthusiastic about proposed industries, then they should also be enthusiastic about the benefits of industrial development. 
As one might expect, there was a strong correlation between perceived benefit of the industries and attitudes favoring versus opposing the developments. Those who favored the industries perceived them as beneficial to the area significantly more than those who opposed them (Figure 12). Nonetheless, this was not a perfect correlation and the two variables remain distinct. For example, whereas the authors found that males favored the industries significantly more often than females (previously discussed), the hypothesized relationship between perceived benefit and sex was not statistically significant.

Education was inversely related to perceived benefit. As predicted, respondents with lower levels of education perceived the new industries to be beneficial more frequently than did more highly educated respondents (Figure 13).

Similarly, residents occupationally classified as blue collar and service workers also thought the area would benefit from the industries more often than did those in white collar positions (Figure 14). This also proved to be the case for workers in energy-related occupations (Figure 15).

Although the pilot study had suggested that older people in the area tended to favor the industries more often than younger people, no relationship was found between perceived benefit and age in the MAS data.

To expand the analysis, relationships between perceived benefit of local industrial growth and residents' assessments of the local quality of life was

Figure 12.

Perceived benefit of new industries by favor versus oppose new industries

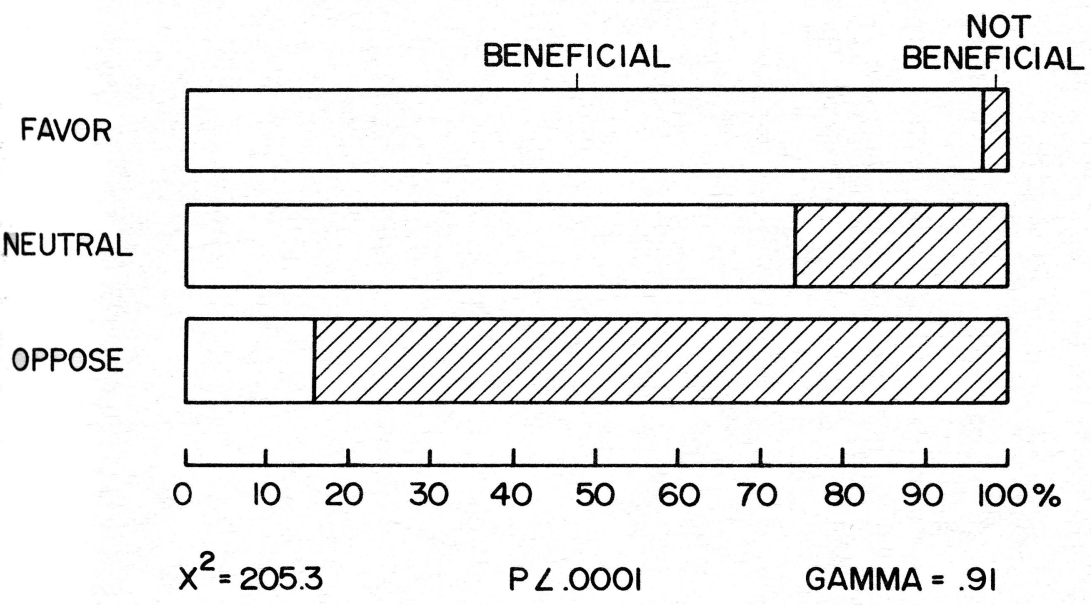


Figure 13.

Perceived benefit of new industries

by education

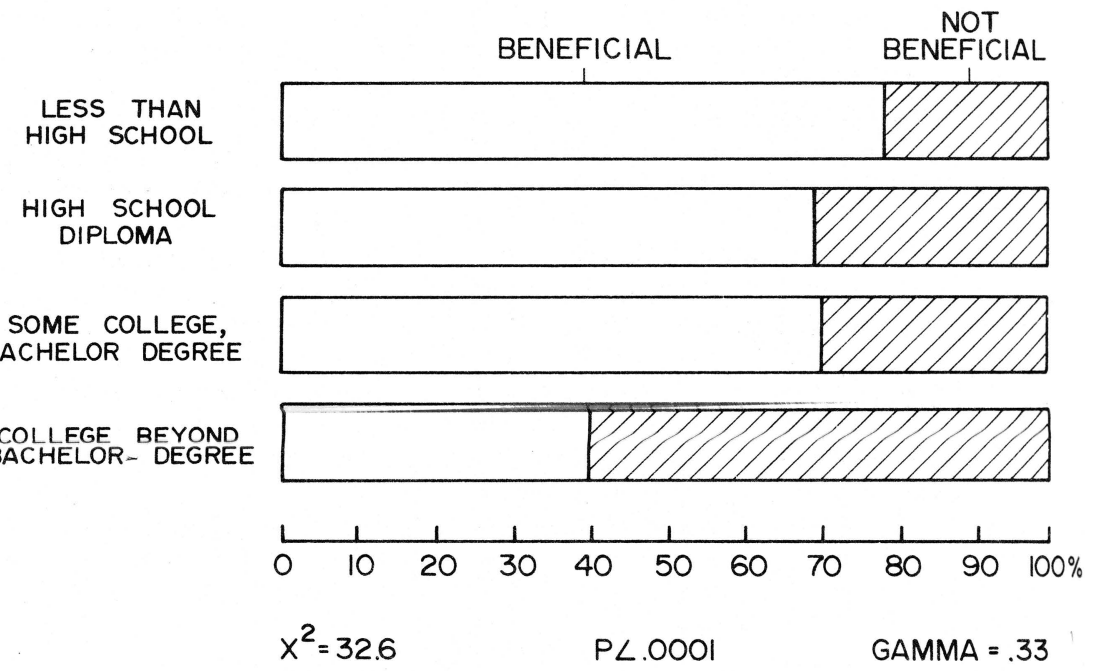

Figure 14.

Perceived benefit of new industries by occupation class

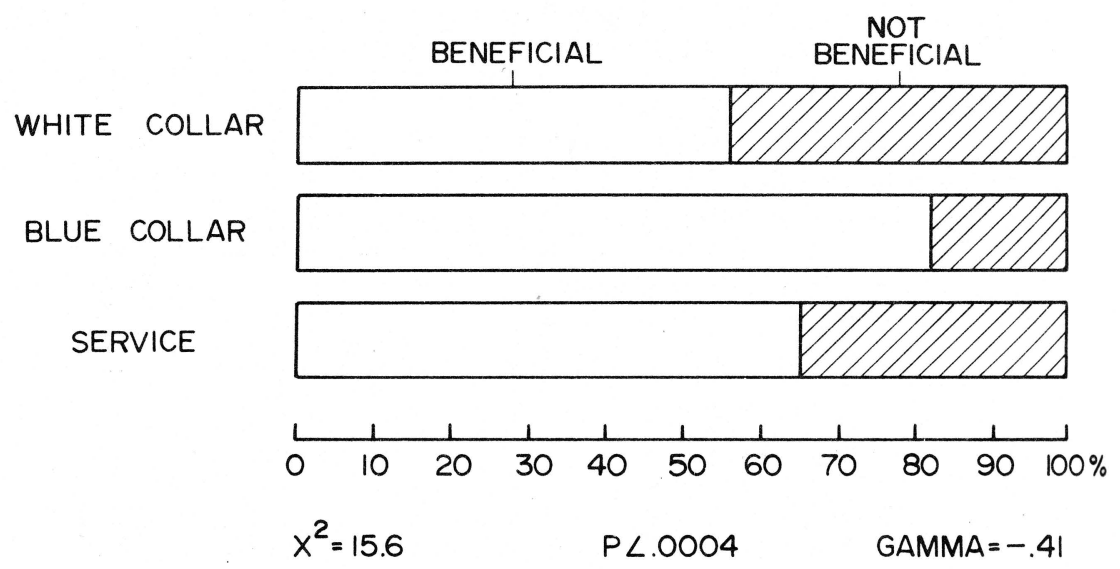




\section{Figure 15. \\ Perceived benefit of new industries by energy-related occupation}

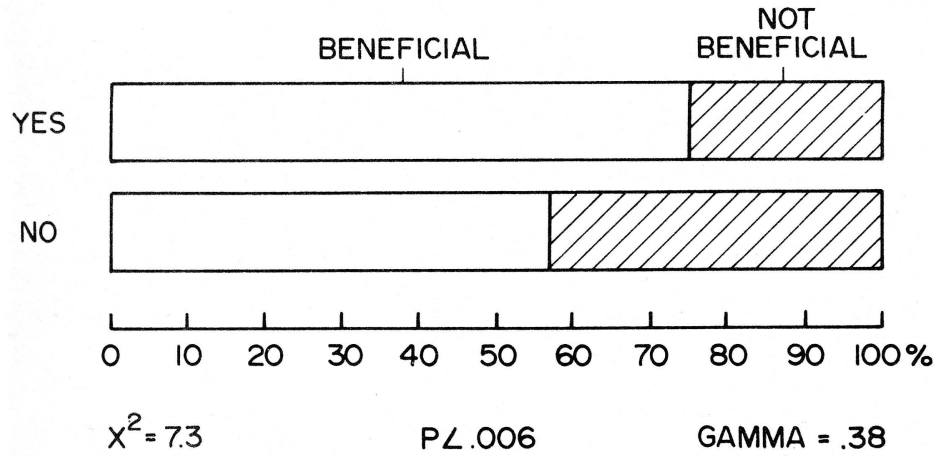

examined. We reasoned that feelings about life in the Monongalia area would influence feelings toward industry, with its capacity for making lifé better or worse.

Residents who are proud of the area (Figure 16) and who believe it is a good place to raise children (Figure 17) are likely to believe the proposed industries will bring benefits. This belief was also stronger among residents who want to see the area population increase than among those who wish for population stability or decline (Figure 18).

Figure 16.

Perceived benefit of new industries by how proud of local area

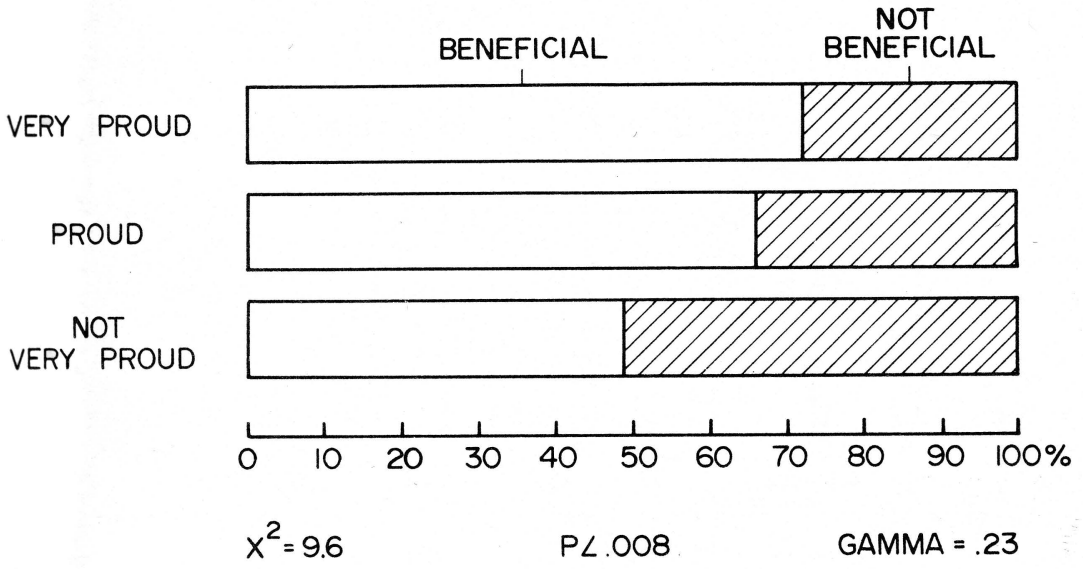




\section{Figure 17. \\ Perceived benefit of new industries by good place to raise children}

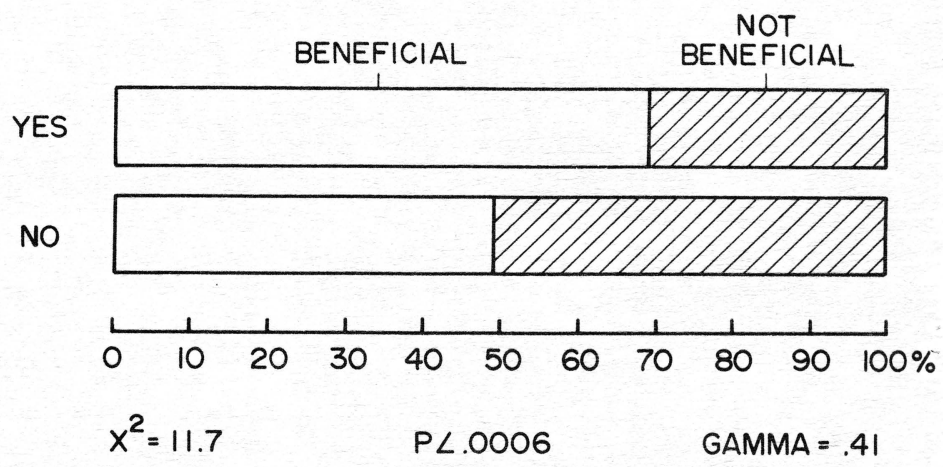

Figure 18.

Perceived benefit of new industries by desired change in local population

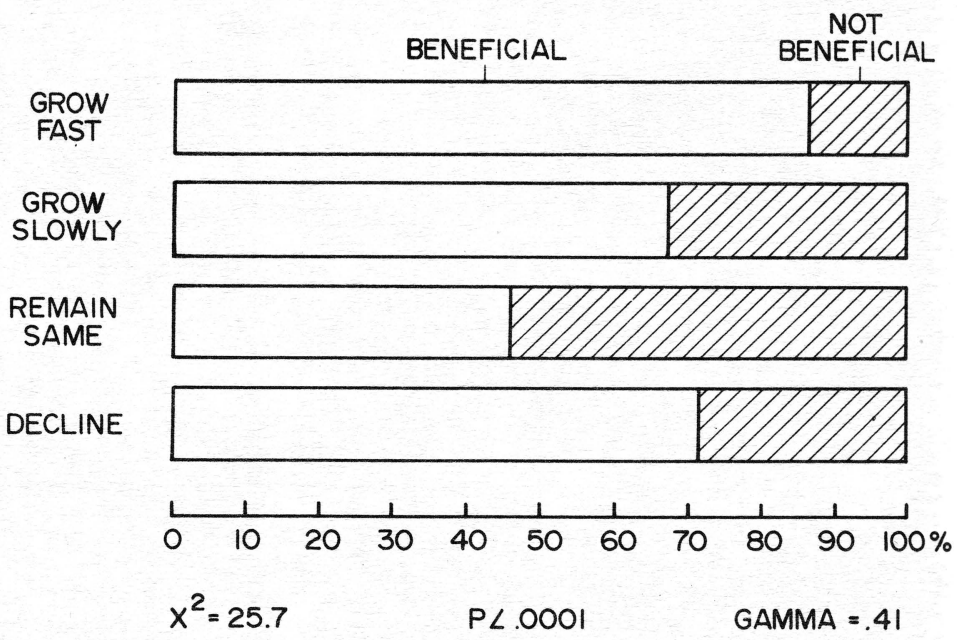

In contrast, residents who professed environmental protection as a value were less likely to perceive benefits from energy-related industrial, development. Respondents who favor environmental protection over either energy production or economic growth tend to believe the proposed projects will not benefit the Monongalia area (Figures 19 and 20). 
Figure 19.

Perceived benefit of new industries by environment versus energy

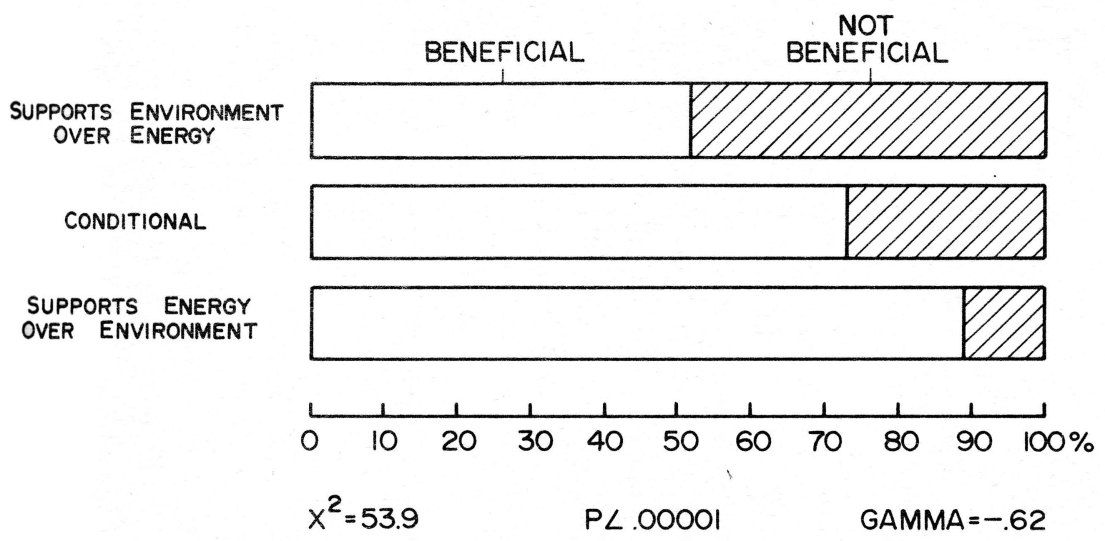

Figure 20.

Perceived benefit of new industries by environment versus economic growth

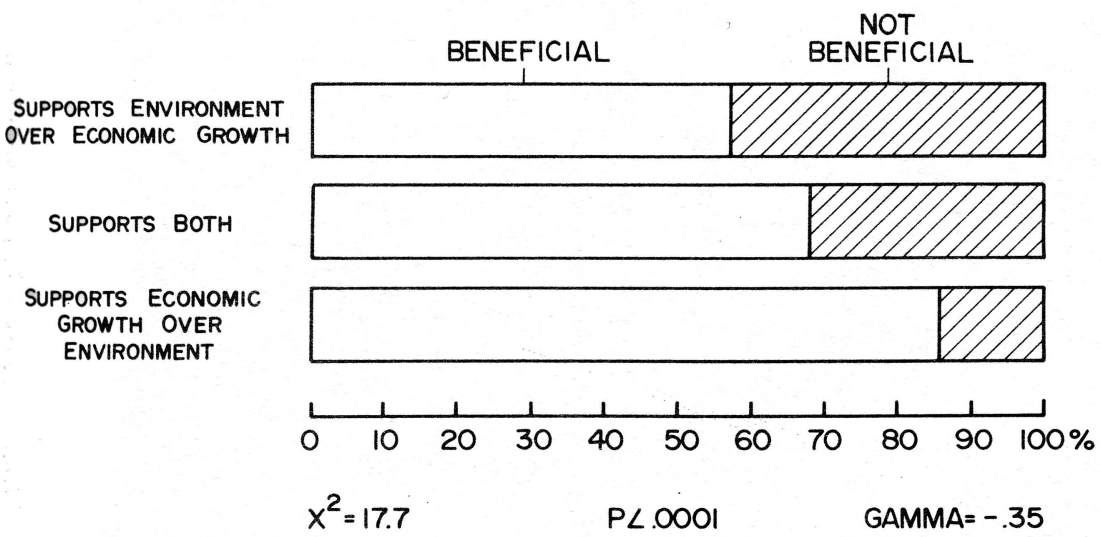

In this same vein, those who perceived air pollution and water pollution as problems in the area felt that the area would not benefit from energy developments significantly more often than did those who did not think there were pollution problems in the area (Figures 21 and 22).

In sum, the people who live in the area most likely to be affected by these energy-related industries thought the area will benefit from them. It also 
Figure 21.

Perceived benefit of new industries by

perceived problem of air pollution

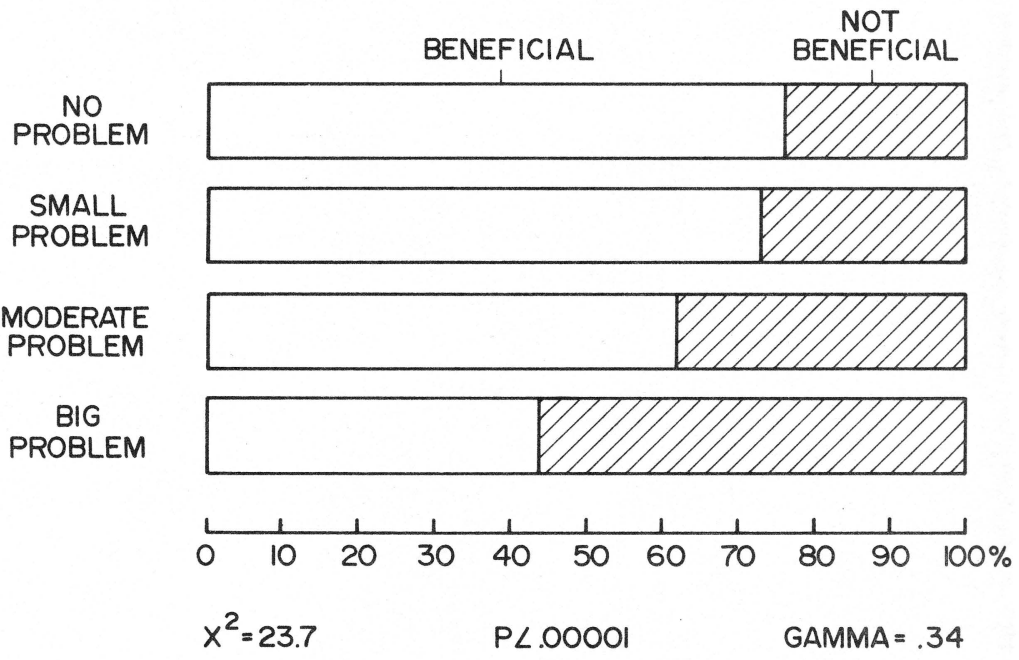

Figure 22.

Perceived benefit of new industries by perceived problem of water pollution

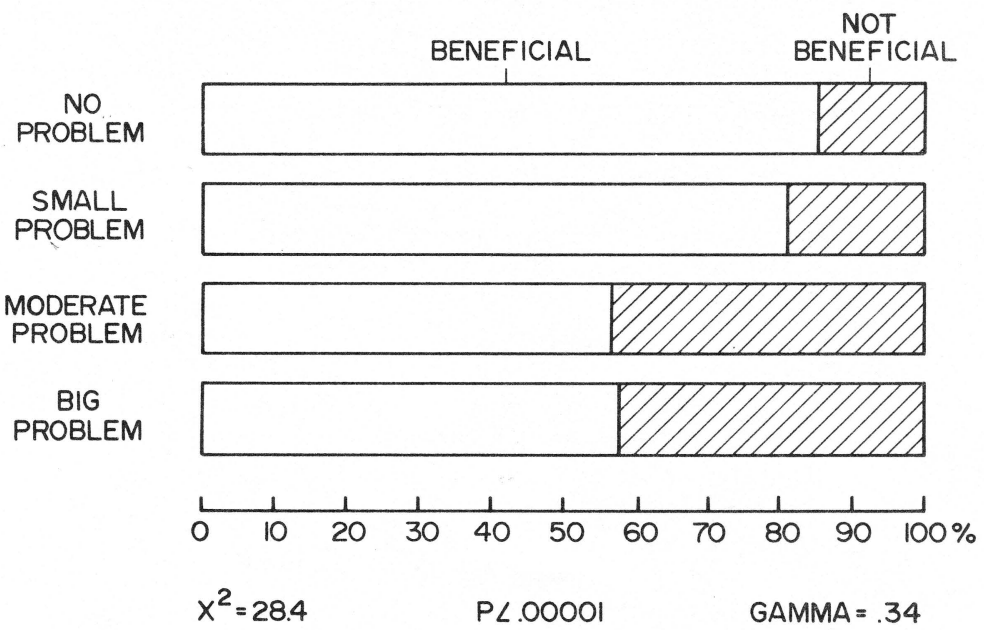


appears that groups of people who have certain socioeconomic characteristics in common perceive the industries as beneficial more often than others. Area residents with lower levels of education, those in blue collar and service occupations, and those who have energy-related occupations are more likely to see the industries as beneficial to the area than highly educated residents, those with white collar jobs, and those with jobs that are not related to the energy industry.

Residents who have pride in the area and who think it is a good place to raise children also perceived the projects as beneficial. However, those who felt that air pollution and water pollution are problems in the community did not think the area would benefit from the energy developments. Similarly, those who are more concerned with adequate energy and with economic growth envisioned the developments as more beneficial than did those who are more concerned with the environment.

If it were possible to select a simple model to interpret the findings reported in this section, it would probably be called a "pocketbook" model. Many of the differences between groups can be interpreted as reflections of economic selfinterest: the generally favorable views of local developments held by blue collar workers, workers in the energy industry, and people who are attached to the local area would seem to be in their broad economic self-interest. Still, there are bound to be complicating factors. One large complication derives from the fact that not all benefits and costs are easily expressed in economic terms.

As reported, the authors consistently found differences between men and women in views of industries, pollution, and the environment. Consistent sex differences seemingly do not fit a pocketbook model since most of our respondents were married (66 percent) and thus were part of a household economy in which the economic interests of the breadwinners coincide with the economic fate of the household. Then why are men generally more favorable toward industries and less environmentally oriented? Possibly women, particularly those with children, are more sensitive to those intangible benefits and costs grouped under the heading "quality of life." To the extent that women are more likely to occupy domestic roles they may be in a better position to give weight to some of the intangible costs that big industries inevitably bring into an area along with economic benefits.

A second area deserving of careful consideration in future research revolves around the non-adversary stance that most people take toward local industrial development. In the Monongalia area, one gained the impression from the media that the issue of new industries had sharply polarized the citizenry of the area. In terms of the public debate, as it was carried out in the newspapers and public meetings, one got the impression that it was a battle royal between industrial and business interests, on the one hand, and environmentalists on the other. Both economic interest and environmentalism are evident in our data, but the basic picture is not that of polarized factions, but rather a large majority of silent citizens who both want new industries and want a good quality of life, including clean air and water. Individual perceptions of the potential impacts of developments inherently involve a trade-off between these two types of benefits and costs associated with economic development: tangible, economically measurable benefits and costs (e.g., employment opportunities, increased business activities) versus intangible, hard to measure benefits and costs (e.g., pollution, inadequate public services). The 
findings in this study appear to indicate that trade-off points vary according to the socioeconomic characteristics of individuals. Although these trade-off points could not be quantified in this research, the variations in residents attitudes toward energy development provide important insight into the socioeconomic adjustment process of Appalachian communities facing energy-related developments. By determining the nature and role of both perceived tangible and intangible benefits and costs the authors could better explain the social processes underlying the political debates that occur in connection with the siting of new industrial developments, particularly those involving energy.

\section{HOW ARE STUDENTS DIFFERENT FROM OTHER LOCAL RESIDENTS?}

So far this bulletin has focused on the non-student portion of the adult population. Students differ from other area citizens in several important ways. Since WVU is a large university in a small metropolitan area, few students are able to commute from their parents' homes. So, unlike a big city university, WVU has few part-time and commuting students and it has many full-time, residential students. Add to this the fact that most WVU graduates seek jobs where the opportunities are, that is, away from Morgantown, and we see that WVU students tend to be more transient members of the local community. The University student has a much different stake in the community than does the non-student resident, who is generally older, more permanent, and whose interests may be more intimately tied to the local economy. For all of these reasons the authors chose to consider students separately as a distinct kind of local citizen who might be expected to regard local development in a different light, consistent with their unique relationship to the community.

On the other hand, the split between "town and gown" is somewhat fuzzy, and it may be that students differ from non-students ("townspeople") in some ways but not others. The researchers were mainly interested in students' views on local industrial development, and on energy, the economy, and the environment. They did not solicit students'opinions on local services and local problems.

Earlier data were presented to show that most townspeople in the survey strongly support the values of the environmental movement, at least as regards the desirability of clean air and water. Indeed, the study showed that there was almost no tendency for townspeople to be pro-industry or pro-energy at the expense of clean air and water, but local industrial development was seen as desirable nevertheless. The authors expected students to be more pro. environment and less pro-industry than townspeople, but, as the results will show, the picture is more complicated than that.

How are students tied into the community? It was noted earlier that students are transients. Any casual observer of the local scene knows they differ from townspeople in other ways. Table 4 shows that student respondents are muct younger than townspeople-87 percent of them being under 26 years of age compared to 15 percent of the townspeople being that age. (In fact, withou WVU the Morgantown area would have a rather elderly population, so typica of out-migration a reas such as Appalachia and parts of New England.) Studen 
Table 4.

Comparison of Students and Townspeople

According to Age, Dwelling Unit Status

(Own/Rent) and Amount of Monthly Rent.

\begin{tabular}{lccc}
\hline & $\begin{array}{c}\text { Percent in Age } \\
\text { Group 18-25 }\end{array}$ & $\begin{array}{c}\text { Percent Who Rent } \\
\text { Dwelling Unit }\end{array}$ & $\begin{array}{c}\text { Percent of Renters } \\
\text { Who Pay Less Than } \\
\text { \$250 per Month }\end{array}$ \\
\hline Students & 87 & 84 & 40 \\
Townspeople & 15 & 22 & 53 \\
\hline
\end{tabular}

respondents are mostly renters (84 percent), whereas townspeople are infrequently renters (22 percent). Of those respondents who do rent, students actually pay significantly higher rents than townspeople (Figure 23). This may reflect the fact that many of the townspeople actually live outside Morgantown proper, and almost one-third of the townspeople are past age 55. In other words, students may pay higher rent for the convenience of living close to campus, and townspeople who rent are likely to have rented their residences for many years and therefore have not experienced the same rate of increase in rent as have those in dwellings with rapid turnover in occupancy.

Figure 23.

Comparison of students and townspeople according to monthly rent (Students living in fraternity houses, sorority houses and dorms were excluded)

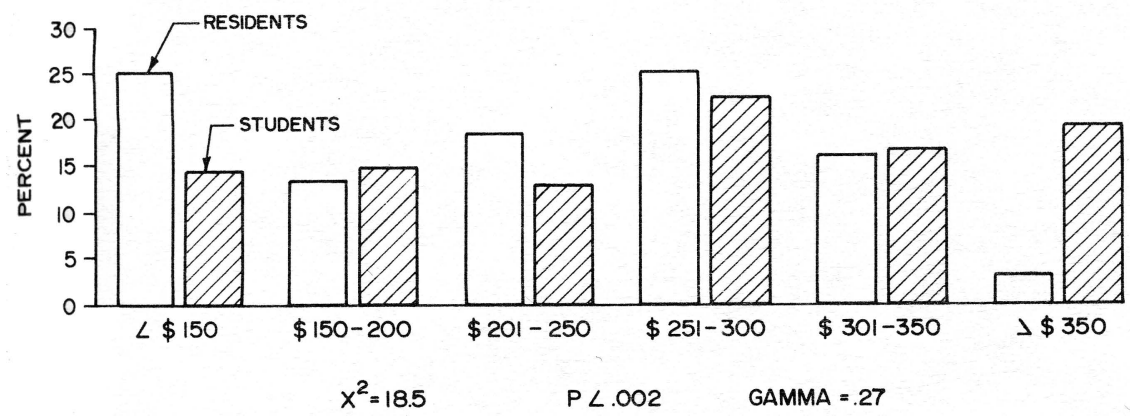

If students are indeed a socially distinct subpopulation of the local area, they are quite likely to view such concerns as industry, energy, the economy, and the environment quite differently. Do students even know as much as townspeople about local developments? For each industry (Table 5, left half) 
townspeople are somewhat more likely to report having heard of a development than are students, the only exception being the coal liquefaction plant. Recognition factors differ less for the two developments proposed for siting closer to Morgantown. In other words, students are somewhat less cognizant of these developments overall than are townspeople.

The right side of Table 5 compares students with townspeople according to how much each development is favored. The differences are much smaller than anticipated. The proportions in favor of the Sharon Coke Plant are about equal, but these figures are based on the small numbers of students and townspeople who know about the plant. The 24 percent of "knowledgable" students may be an unusual group. Toward the other developments, students are less favorable, but they certainly are not radically opposed. In fact, only the Roundbottom Coke Plant failed to muster majority support among "knowledgable" students, with students opposing this industry significantly more than townspeople.

When students were asked rather more general questions concerning these four projects (all lumped together), we obtained the results shown in Table 6. There were only trivial differences between students and townspeople on the questions of whether the projects would be of benefit locally or nationally or whether the respondent would vote for the projects if there were a referendum. The general pro-industrialism of townspeople in the Morgantown area is completely shared by the students.

To inquire further into these differences and similarities, the authors compared students with townspeople on their level of general environmentalism. The first question in Table 7 was a forced-choice between

Table 5.

Comparison of Students and Townspeople in Recognition Factors and Favorability Toward Four Proposed Industries.

\begin{tabular}{lcccc}
\hline & \multicolumn{2}{c}{$\begin{array}{c}\text { Heard } \\
\text { about developments }\end{array}$} & \multicolumn{2}{c}{$\begin{array}{c}\text { Favor } \\
\text { developments }\end{array}$} \\
\hline & $\begin{array}{c}\text { Students } \\
\%\end{array}$ & $\begin{array}{c}\text { Townspeople } \\
\%\end{array}$ & $\begin{array}{c}\text { Students } \\
\%\end{array}$ & $\begin{array}{c}\text { Townspeople } \\
\%\end{array}$ \\
\hline SRC II Plant & 93 & 95 & 65 & 77 \\
$\begin{array}{l}\text { Roundbottom } \\
\text { Plant }\end{array}$ & 68 & $85^{\star \star}$ & 42 & $51^{\star *}$ \\
Sharon Plant & 24 & $44^{\star *}$ & 70 & 69 \\
Industrial & 43 & $55^{\star \star}$ & 51 & 63 \\
Park & 43 & &
\end{tabular}

"Excludes respondents who have not heard of or have no opinion about the developments.

* Significant difference between students and townspeople at the .05 level. 
Table 6.

\section{Comparison of Students and Townspeople}

According to Attitudes Toward Local

Development Projects.

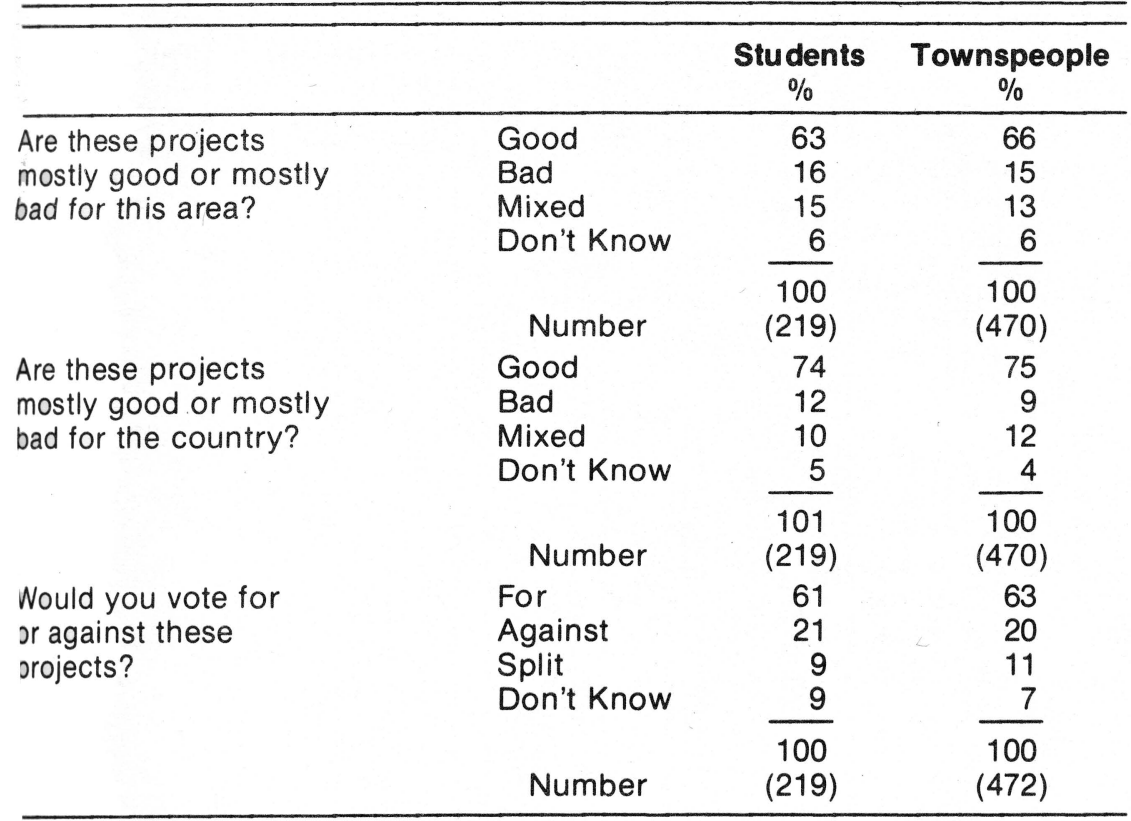

energy production and environmental protection; it is forced in that no conditional or middle of the road answer was offered by the interviewer. However, if a respondent gave an answer such as "Both are equally important," it was recorded as middle of the road. The data show clearly that students and townspeople are equally pro-environment. The second question in Table 7 offered the middle-of-the-road alternative in the wording of the question. The results here are similar to those of the previous question in that students a re no more pro-environment, but neither are they more-pro-economic growth. This seeming paradox results from the fact that students are more likely to favor the middle of the road: economic growth and protection of the environment. Sixtythree percent of the students selected this option, compared to only 47 percent for the townspeople. Although both townspeople and student respondents are generally saying they want both a healthy economy and a healthy environment, townspeople are more likely than students to see the issue as a trade-off wherein the environment and economic growth are incompatible goals.

We can easily imagine why students might be fundamentally similar to other respondents in favoring economic and energy growth (albeit not at the expense of the environment). After all, they will shortly be seeking jobs. So in spite of the fact that their relationship to the community is not the same as for 
Table 7.

Comparisons of Students and Townspeople

According to Energy/Environment and

Economic Growth/Environment Trade-Offs

\begin{tabular}{|c|c|c|c|}
\hline & & $\begin{array}{l}\text { Students } \\
\%\end{array}$ & $\begin{array}{c}\text { Townspeople } \\
\%\end{array}$ \\
\hline $\begin{array}{l}\text { Are you more on } \\
\text { the side of ade- }\end{array}$ & Energy & 29 & 28 \\
\hline $\begin{array}{l}\text { quate energy or } \\
\text { more on the side }\end{array}$ & Environment & 51 & 53 \\
\hline of protecting the & Middle-of-the-road & 18 & 15 \\
\hline \multirow[t]{2}{*}{ environment? } & Don't Know & 1. & 4 \\
\hline & Number & $\begin{array}{c}99 \\
(218)\end{array}$ & $\begin{array}{c}100 \\
(481)\end{array}$ \\
\hline \multicolumn{4}{|l|}{$\begin{array}{l}\text { Which statement do you } \\
\text { agree with? }\end{array}$} \\
\hline $\begin{array}{l}\text { We must relax en- } \\
\text { vironmental standards } \\
\text { in order to achieve } \\
\text { economic growth. }\end{array}$ & Economic growth & 7 & 13 \\
\hline $\begin{array}{l}\text { We must accept } \\
\text { a slower rate of } \\
\text { economic growth } \\
\text { in order to pro- } \\
\text { tect the environ- } \\
\text { ment. }\end{array}$ & Environment & 30 & 36 \\
\hline \multirow{3}{*}{$\begin{array}{l}\text { We can achieve } \\
\text { environmental } \\
\text { protection and } \\
\text { economic growth } \\
\text { at the same time. }\end{array}$} & Middle-of-the-road & 63 & 47 \\
\hline & Don't Know & 0 & 4 \\
\hline & Number & $\begin{array}{l}100 \\
(219)\end{array}$ & $\begin{array}{c}100 \\
(481)\end{array}$ \\
\hline
\end{tabular}

townspeople, there is a basis for agreement on the desirability of growth. (This is not to say that students and townspeople share all interests; they obviously do not). Why does this conclusion run counter to the expectations the researchers held before analyzing the data? Students tend to have high participation rates in environmental organizations that get media coverage. The behavior of the more active and articulate organizational joiners who claim our attention is a poor indicator of how the others feel. Most students in the study must be characterized as very similar to townspeople in their priorities for local industrial development, energy growth, economic growth, and the need to protect the environment. 


\section{DISCUSSION}

At this time, the industrial future of the Monongalia area is anything but clear. Three of the four developments asked about in the survey-SRC-II Liquefaction Plant, Roundbottom Coke Plant, and Sharon Coke Plant-now seem to be abandoned. Attempts are still being made to establish an industrial park in the area, but groundbreaking appears to be no closer now than it was in March, 1981, when this survey was conducted. In the Monongalia area as elsewhere, economic growth and decline depend as much on decisions made in Washington, New York and other seats of economic power as they do on decisions made by local planners and entrepreneurs. The authors have assumed that industrial growth will be coming to the area, either sooner or later, and that considerable growth is almost inevitable because of our coal. Although specific projects may come or go, planning for growth makes good long-range sense.

The MAS shows that the area is not dominated by the largely blue collar coal industry or by the largely white collar university. Many citizens are deeply rooted here, despite the transience generated by WVU. It is not surprising that concern with quality of life runs high, somewhat contrary to the popular stereotype of Appalachia as an exploited land inhabited by exploited people. If anything, the respondents may be more concerned about environmental quality than citizens nationally.

This concern with quality of life and the natural environment translates not into an anti-industrial mood, but rather into a sense that the area should be able to have a growing industrial base and provide a decent living environment as well. The desire for both growth and quality of life is especially clear among the students, almost all of whom are under 25 and who will shape the future. It is very clear from the survey, as well as from community reaction to specific developments, that a roughshod, public-be-damned industrialism is a relic from an earlier era.

It is more difficult to comment on whether residents' hopes and fears are realistic. Many surveys have found enthusiasm for industrial development in rural communities, even though some residents objectively stand to benefit much more than others. The support for development on behalf of the landbased elite is an expression of simple economic self-interest (Molotch, 1976). More intensive land use and greater population pressure means generally more profits for anyone holding local non-liquid assets, even a house. On the other hand, slow growth rates, stability or decline in the local economy undercut almost all investments. To what extent are area residents members of the land-based elite? Relatively few people actually own businesses or make profit from real estate holdings, but a firm majority of the townspeople in this sample own their own home.

Economic self-interest in growth based on property holding may be rare or common depending on how people see the value of their home as subject to economic trends, but all citizens are affected by environmental quality and the quality of local services. This research shows clearly that concern with various aspects of quality of life varies according to respondents' characteristics, but overall, residents are not prepared to sacrifice much for the sake of industrial growth. 
How much would residents benefit from industrial growth in the area? Members of the land-based elite almost inevitably gain, but the prospects for citizens as job seekers, taxpayers, consumers of services, and members of a friendly, rural community are less clear. The Journal of the Community Development Society published a paper in 1977 which reviewed 186 studies of impacts of new factories in rural areas (Summers, 1977). If the experience of these 186 rural communities is typical, there are both benefits and disadvantages, and they are not equally distributed:

Stimulating the economic life of non-metro communities by encouraging manufacturing location creates benefits and problems. There are new jobs; but few are filled by local economically disadvantaged cítizens. Per capita income increases; but gains are unequally distributed. Population frequently grows, primarily due to in-migration. While more people stimulate local markets they also generate demands for public services with the result that gains in the fiscal base of local governments often are exceeded by costs of service delivery. Ind ustrial development of rural areas produces positive gains to owners of local economic assets. It will have a small or even negative effect on local government and economically disadvantaged citizens.

Despite the mixed picture of benefits, residents of rural areas almost always overwhelmingly favor new developments (Maurer and Napier, 1981), and the Monongalia area is not an exception to this rule. However, area residents are also concerned about the quality of their living environment and generally fee that the anticipated growth and development of the area requires prio planning. 


\section{BIBLIOGRAPHY}

Catton, W. R. and R. E. Dunlap, 1978. "Environmental Sociology: A New Paradigm," The American Sociologist 13:41-59.

Council on Environmental Quality, Department of Agriculture, Department of Energy and Environmental Protection Agency, 1980. Public Opinion on Environmental Issues: Results of a National Public Opinion Survey. U.S. Government Printing Office, Washington, D.C.

Gilmore, J. S. and M. K. Duff, 1975. Boomtown Growth Management; A Case Study of Rock Springs-Green River, Wyoming. Westview Press, Boulder, Colo.

Gold, R., J. Devitt and A. Sterling, 1974. A Comparative Case Study of the Impact of Coal Areas of Eastern Montana and Northeastern Wyoming. University of Montana, Institute of Social Research, Missoula.

Gulley, D. A., 1976. "Forecasting Community Impacts Due to Mineral Development," Proceedings of the Council of Economics, 105th Annual Meeting. American Institute of Mining and Petroleum Engineers, Colorado School of Mines, Boulder.

Krutilla, J. V., A. C. Fisher and R. E. Rice, 1978. Economic and Fiscal Impacts of Coal Development; Northern Great Plains. Johns Hopkins University Press, Baltimore.

Lawyer, R. E. 1966. "An Air Pollution Public Opinion Survey for the City of Morgantown, West Virginia." Master's thesis, College of Engineering, West Virginia University, Morgantown.

Maurer, R. C. and T. L. Napier, 1981. "Rural Residents' Perspectives of Industrial Development," Rural Sociology 46 (Spring):100-111.

Molotch, H. 1976. "The City as a Growth Machine: Toward a Political Economy of Place," American Journal of Sociology 82 (September):309-32.

Moreland, D. H., ed., 1981. Statistical Profiles of West Virginia University: 1979-1980, Tenth Edition. Office of Institutional Research, West Virginia University, Morgantown.

Stout-Wiegand, N., R. B. Trent and D. K. Smith, 1981. A Pilot Socioeconomic Survey of the Impact Area of Energy-Related Industries Proposed for Monongalia County, West Virginia. West Virginia University Agricultural and Forestry Experiment Station, Morgantown.

Summers, G. F. and F. Clemente, 1976. "Industrial Development, Income Distribution and Public Policy," Rural Sociology 41 (Summer):248-268.

Summers, G. F. 1977. "Industrial Development of Rural America: A Quarter Century of Experience," Journal of Community Development Society 8 (Spring):6-18.

U.S. Bureau of the Census, 1980. Preliminary Population and Housing Unit Counts: West Virginia. PHC80-P-50. U.S. Department of Commerce, Washington, D.C. 
Blank Page in Original Bulletin 
Blank Page in Original Bulletin 